\title{
Türkçe Öğretmeni Adayları Osmanlı Türkçesi Dersi Hakkında Ne Düşünüiyor?*
}

\section{What Are Opinions of Turkish Teacher Candidates on Ottoman Turkish Courses?}

\author{
Hayrullah KAHYA ${ }^{1}$
}

*Bu makale 12-13 Aralık 2019 tarihlerinde İstanbul'da düzenlenen VI. Yıldız Uluslararası Sosyal Bilimler Kongresi'nde sözlü bildiri olarak sunulmuş bildirilerin gözden geçirilmiş ve genişletilmiş hâlidir.

${ }^{1}$ Sorumlu yazar/Corresponding author: Hayrullah Kahya (Doç. Dr.),

Yıldız Teknik Üniversitesi, Eğitim Fakültesi, Türkçe Eğitimi Anabilim Dalı, İstanbul, Türkiye. E-posta: hayrullahkahya@hotmail.com ORCID: 0000-0002-1192-6453

Başvuru/Submitted: 24.12 .2019 Revizyon Talebi/Revision Requested: 20.03.2020

Son Revizyon/Last Revision Received: 26.04.2020

Kabul/Accepted: 05.05.2020

Online Yayın/Published Online: 12.06.2020

Atıf/Citation: Kahya, Hayrullah. "Türkçe Öğretmeni Adayları Osmanlı Türkçesi Dersi Hakkında Ne Düşünüyor?" Türkiyat MecmuasıJournal of Turkology 30, 1 (2020): 129-160 https://doi.org/10.26650/iuturkiyat.664568 öz

Osmanlı Türkçesi, 15. yüzyıldan itibaren genel olarak Osmanlı İmparatorluğu'nun hüküm sürdüğü topraklarda kullanılmış Türkçenin tarihî bir lehçesidir. Bu lehçe 20. yüzyıldan itibaren yerini Türkiye Türkçesine bırakmıştır. Bu lehçenin dilbilimsel sürekliliği bakımından Türkiye Türkçesi ile yakın bir ilişkisi bulunmaktadır. Bu çalışmada Türkçe öğretmeni adaylarının Türkçe Eğitimi Ana Bilim Dalı'nda haftada iki saat olmak üzere zorunlu olarak iki dönem hâlinde okutulan Osmanlı Türkçesi dersi hakkındaki görüşleri tespit edilmeye çalışılmıştır. Çalışmanın amacı Osmanlı Türkçesi derslerinin sağlıklı bir şekilde düzenlenmesi ve uygulanması için Türkçe öğretmen adaylarının görüşlerini toplayıp yorumlamak ve buna bağlı olarak gereken düzenlemelerin yapılması için konunun paydaşlarına önerilerde bulunmaktır. Çalışma, nicel ve nitel modelde desenlenmiş karma bir araştırmadır. Veriler betimsel analiz yöntemlerine göre analiz edilmiştir. Veriler amaçlı örneklem yöntemine uygun olarak Türkiye'deki 15 farklı üniversitenin Türkçe Eğitim Ana Bilim Dalı́nda eğitim gören 277 Türkçe öğretmen adayından gönüllülük esasına göre elde edilmiştir. Katılımcılar Osmanlı Türkçesi dersini almış olan 2., 3. ve 4. sınıf öğrencilerinden oluşmuştur. Araştırmanın sonucunda katılımcıların çoğunun Osmanlı Türkçesi dersine ilişkin genel ilgi, düşünce ve tutumlarının olumlu olduğu tespit edilmiştir. Katılımcıların çoğunluğu dersin Türkçe eğitiminin amaçlarına uygun olduğunu da belirtmişlerdir. Katılımcıların büyük bölümü kendilerini dersin gerektirdiği akademik düzey açısından yeterli görmemektedir. Buna rağmen dersin süresinin ve içeriğinin Türkçe öğretmeni adayları için uygun olduğunu ve dersin zorunlu yerine seçmeli olması gerektiğini düşünmektedirler. Araştırma sonucunda ortaya çıkan bu ve benzeri tutarsızlıkların giderilmesi, dersin daha işlevsel ve verimli hâle getirilmesi için bazı önerilerde bulunulmuştur.

Anahtar kelimeler: Osmanlı Türkçesi, Türk dili, Türkçe öğretmeni adayları, Türkçe Eğitimi, Türkçe, Öğrenci görüşleri

\section{ABSTRACT}

Ottoman Turkish is the name used for the Turkish language which was spoken in the territories dominated by the Ottoman Empire between the $15^{\text {th }}$ and $20^{\text {th }}$ centuries. Ottoman Turkish has given place to modern Turkish since the $20^{\text {th }}$ century. In terms of historical continuity, Ottoman Turkish and modern Turkish 
have a close linguistic relationship. This study attempts to determine the opinions of Turkish teacher candidates on the mandatory Ottoman Turkish course which was taught in two terms for two hours a week at the department of Turkish language teaching. The aim of the study is to collect and interpret the opinions of Turkish teacher candidates on the appropriate organization and implementation of Ottoman Turkish lessons and to make suggestions to the stakeholders concerned, so that they can make any necessary adjustments. The study is a mixed study designed in a quantitative and qualitative model. The data were analyzed according to the descriptive analysis method. These data were obtained in accordance with the data sampling method from 277 volunteers, all Turkish teacher candidates who are studying at the department of Turkish language education in 15 different universities in Turkey. The participants consisted of $2^{\text {nd }}, 3^{\text {rd }}$ and $4^{\text {th }}$ grade students who took the Ottoman Turkish course. It was seen that most of the participants' general opinions, thoughts and attitudes towards the Ottoman Turkish course were very positive, and most of them stated that the course was appropriate for the aims of Turkish education. Most of them did not consider themselves to be of a sufficient level to do justice to the course. They also thought that the duration and content of the course was sufficient and that it should be an elective course. Some suggestions were made to eliminate any inconsistencies arising from the research and to make the course more functional and efficient.

Keywords: Ottoman Turkish, Turkish language, Turkish teacher candidates, Turkish language education, Turkish, opinions of students

\section{EXTENDED ABSTRACT}

Turkish is a language with a history of thousands of years. Ottoman Turkish belongs within the historical period of the Turkish language which was used between the $15^{\text {th }}$ and $20^{\text {th }}$ centuries in the lands dominated by the Ottoman Empire. Modern Turkish started in the $20^{\text {th }}$ century after Ottoman Turkish finished. So, Ottoman Turkish has a close linguistic relationship with modern Turkish in terms of historical continuity. For this reason, Ottoman Turkish is extremely important for modern Turkish. Ottoman Turkish is currently taught as a subject to varying degrees in some universities in Turkey, mainly in departments of Turkish Education, History, Turkish Language and Literature, and Information and Document Management. In fact, it is seen that Ottoman Turkish as a course has entered education programs at different levels in other types of high school, especially in Social Sciences High Schools in recent years. This study attempted to determine the opinions of Turkish teacher candidates on Ottoman Turkish 1 and Ottoman Turkish 2 courses which were taught over two terms for two hours a week. The aim of the study is to collect and interpret the opinions of Turkish teacher candidates regarding the appropriate organization and implementation of Ottoman Turkish courses and to make suggestions to the stakeholders about the subject in order to make necessary adjustments accordingly. The study is a mixed study designed in a quantitative and qualitative model. The data were analyzed according to the descriptive analysis method. In the study, a structured likert type questionnaire was used. Frequency and percentage values of the quantitative data were analyzed. Validity and reliability analyses of the scale were also performed. The data was obtained in accordance with the data sampling method from 277 volunteers, all of whom are Turkish teacher candidates who are still being educated in Turkish Education Departments in 15 different universities in Turkey. The participants' thoughts on the following topics, consisting of a total of 35 items, were organized into nine different categories. The topics ranged from the existence, fulfillment and requirements of Ottoman Turkish courses, their contribution 
to the cognitive/academic development of students, their emotional development, their selfconfidence, their professional development, their employment, their contribution to cultural and historical sensitivities, their interest and attitudes towards other courses, and the course content of Ottoman Turkish 1 and Ottoman Turkish 2 courses taught at the Department of Turkish Education in the undergraduate program. At the bottom of the form, participants were also asked to write any ideas they would like to express on addition to the items on the form. Thus, the aim was to determine the opinions of the participants on subjects not mentioned on the form. This section constitutes the qualitative dimension of the scale. According to the data, the general opinions, thoughts and attitudes of the participants were positive according. The majority of the participants stated that the Ottoman Turkish 1 and Ottoman Turkish 2 courses were suitable for the aims of the Turkish Education Department in universities. Most of them did not consider themselves to be sufficient for the demands of the courses. They also thought that the duration and content of the course was sufficient but that it should be an elective course. In our opinion, this latter statement showed an inconsistency in thinking. In order to overcome this and similar inconsistencies, some suggestions were made to the lecturers of Ottoman Turkish at the universities. For example, Ottoman Turkish course instructors should instruct candidates as to what the priorities of the Ottoman Turkish courses are, what the requirements are in terms of teaching the Turkish language, and what contribution such courses make to the teaching of modern Turkish. This information can be given in a convincing, persuasive and exemplary narrative. Suggestions could be made to try to overcome the prejudices held by Turkish teacher candidates that the course is difficult. However, when conducting the course, it might also be beneficial for the lecturer to consider that the students' levels of readiness for the course may be different. Although the participants are of the opinion that the duration and content of the course is sufficient for them, it is understood that the current Ottoman Turkish course training is not sufficient for the Turkish teacher candidates to gain proficiency in Ottoman Turkish during the course. For this, it could be suggested that the duration of the courses in the department of Turkish education might be extended to three hours instead of two hours a week, and the course should be continued as elective or compulsory in the $2^{\text {nd }}, 3^{\text {rd }}$ and/or $4^{\text {th }}$ grades. Indeed, it is envisaged that most of the knowledge and skills acquired in the course, taken only for two hours a week in the first year, will not become obvious until the graduation of the students. Solving this problem is even more important when we consider that Ottoman Turkish could be given as an elective or compulsory course in primary or secondary education. 


\section{Giriş}

Türklerin Anadolu'ya göçü ve burasını yurt edinmeleri ile Anadolu ve Balkanlarda oluşan Türkçeye genel olarak Batı Türkçesi denilmektedir. 13. yüzyıldan günümüze kadar devam eden bu dönem, dil bakımından kendi içinde Eski Anadolu Türkçesi, Osmanlı Türkçesi ${ }^{1}$ ve Türkiye Türkçesi olmak üzere üç ana döneme ayrılır. 13-15. yüzyılları içine alan Eski Anadolu Türkçesi döneminden sonra 15-20. yüzyıllar arasını kapsayan dönem ise Osmanlı Türkçesi dönemidir. Ergin, ${ }^{2}$ Osmanlı Türkçesini içinde barındırdığı yabancı unsurlar bakımından üç döneme ayırır: ${ }^{3}$

1. Arapça ve Farsça unsurların Türkçeye yoğun olarak girmeye başladığı dönem. Bu dönem 15. yüzyılın sonu ile 16. yüzyılın büyük bölümünü içine alır. Bu dönemde dil içindeki Arapça ve Farsça unsurlar Eski Anadolu Türkçesine göre daha fazla, ancak kendinden sonraki dönemlere göre daha azdır.

2. Dil içindeki Arapça ve Farsça yoğunluğun çok fazla olduğu dönem. Bu dönem 16. yüzyılın sonu ile 17 ve 18 . yüzyılları içine alır.

3. 19. yüzyılın ortalarından 20. yüzyılın başlarına kadar süren üçüncü dönemde dilde Arapça ve Farsça yoğunluğu yavaş yavaş kaybolmaya başlamıştır.

Bu dönemlerden ilkine Osmanlı Türkçesinin başlangıç, ikinci dönemine klâsik, üçüncü dönemine ise yenileşme dönemi de denebilir ${ }^{4} \mathrm{ki}$ bu adlandırma günümüzde daha yaygın olarak kullanılmaktadır.

Bilim çevrelerinde Osmanlı Türkçesi terimi ile Osmanlı İmparatorluğu'nun hâkim olduğu topraklarda konuşulan ve Arap harflerine dayalı bir alfabe ile yazılan Türkçe kasdedilir. ${ }^{5} \mathrm{Bu}$ dil, Tanzimat döneminde "Osmanlıca” olarak adlandırılmış ve "Türkçe, Arapça ve Farsçadan mürekkep bir lisan.” olarak tanımlanmıştır. ${ }^{6}$ Bazı araştırmacılar ${ }^{7}$ da Osmanlı Türkçesinde yoğun Arapça ve Farsça etkisinde yazılmış kimi metinleri örnek göstererek Osmanlı Türkçesini “Türkçenin doğal gelişme sonucu biçimlenmiş bir aşaması değil”, saray çevresindeki yüksek sınıfın Arapça, Farsça ve Türkçenin kelime hazinesi ve dilbilgisi kurallarından faydalanarak meydana getirdiği “melez ve yapma bir dil, daha doğrusu bir jargon” olarak tanımlamaktadır.

1 Günlük hayatta ve bazı kitaplarda yaygın olarak kulanılan "Osmanlıca” terimi bilimsel olarak yanlış bir terimdir. Bu terim ilk olarak Tanzimat döneminde ortaya çıkmıştır. İmparatorluğun çöküş ve gerileme devrinde kurtarıcı düşüncelerden biri olan Osmanlıcılık akımı çerçevesinde Osmanlı İmparatorluğu'ndaki halkı ifade etmek üzere kullanılan "millet-i Osmaniye" terimine koşut olarak dile de "Osmanlıca" demişlerdir. Tanzimat sonrasında yazılan Türkçe dilbilgisi kitaplarına da genellikle "kavâid-i lisân-1 Osmânî” adı verilmiştir. Hâlbuki Tanzimat'dan önce bu dile Türkçe denilmiştir. bk.A.Sırrı Levend, Türk Dilinde Gelişme ve Sadeleşme Evreleri. (Ankara: TDK, 1972), 11.

2 Muharrem Ergin, Türk Dil Bilgisi (İstanbul: Bayrak, 1997), 19-20.

3 Bu konuda yapılmış başka sınıflandırma denemeleri de yapılmıştır. Örnek olarak bk. F.Kadri Timurtaş, Diller ve Türkçemiz (İstanbul: Alfa, 1996), 43; Zeynep Korkmaz, Türk Dili Üzerine Araştırmalar (Ankara: TDK, 1995), 537; Hayati Develi, Osmanlı'nın Dili (İstanbul: Kesit, 2013), 43.

4 bk. Mustafa Özkan, Tarih İçinde Türk Dili (İstanbul: Filiz, 1997), 88-95; Nurettin Demir ve Emine Yılmaz, Türk Dili El Kitabı (Ankara: Grafiker, 2016), 91.

5 Hayati Develi, Osmanlı’nın Dili (İstanbul: Kesit, 2013), 9.

6 A.Sırrı Levend, Türk Dilinde Gelişme ve Sadeleşme Evreleri (Ankara: TDK, 1972), 11.

7 Örnek olarak bk. Süer Eker, Çağdaş Türk Dili (Ankara: Grafiker, 2013), 105. 
Hâlbuki Osmanlı Türkçesi ile genellikle Osmanlı İmparatorluğu'nun hüküm sürdügü topraklarda konuşma ve yazı dili olarak kullanılan Türkçe anlaşılır. Bu dil, Arap harflerine dayalı Türk alfabesi ile yazılmıştır. Kütüphanelerimiz bu dil ile dil, edebiyat, tarih, felsefe, din, tıp, hukuk, iktisat, astronomi vb. her bilim alanında yazılmış binlerce yazma ve basma eserlerle doludur. Uzun tarihi boyunca tarihî ve sosyal ilişkiler içinde bulunduğu Arapça ve Farsçadan birçok kelimeyi bünyesine katmış, bunların birçoğunu da Türkçe telaffuza uydurarak veya bunlara yeni anlamlar yükleyerek Türkçeleştirmiştir. Bu hususu, zamanın siyasî ve kültürel ortamı içinde değerlendirmek ve yorumlamak gerekir. Zaman zaman oldukça fazla alıntılar yapıldı̆̆ 1 dönemler olsa da bu dili onun devamı olan Türkiye Türkçesinden ayrı düşünmek doğru değildir. ${ }^{8}$ Çünkü Osmanlı Türkçesinin gelişmesinde Arapça ve Farsça dil unsurlarının yoğunlaşması meselesi sadece yabancı hayranlığına bağlanmamalıdır. Aksine bu durumu bir imparatorluk dili olan Osmanlı Türkçesinin zaman içinde ihtiyaç duyduğu dil ve kültür malzemesini kendi içinde bulamayınca bu ihtiyacını, yakın kültürel iş birliği içinde bulunduğu diğer dillerden temin etmesi ve bunların imkânlarından da faydalanarak dilin gelişimi sağlamaya çalışma çabası olarak değerlendirmek gerekir. ${ }^{9}$

Tarih boyunca başka dillerden hiç etkilenmemiş medenî (gelişmiş) bir dil görülmemiştir. Sadece Pigmeler, yamyamlar gibi gelişmemiş toplumların dili kapalı kalmış, ufuklarını genişletememiştir. Toplumsal ilişkilerin sonucunda dil ve edebiyatların da birbirleriyle karşılaşmaları esnasında kapılar kapatılmaz. Çinli ile komşuysanız Çinceden, Hintli ile komşuysanız Hintçeden, Fars, Arap, Rum, Rus her kim ile komşu iseniz bunlardan ve bunların dillerinden etkilenmemek ve bunları etkilememek mümkün değildir. Dilsiz diyalog ise mümkün değildir. Ayrıca bir dilin kelime hazinesine kattığı ve bin yıldır kullanılan kelimeler artık kazanılmış, fethedilmiş sayılır. ${ }^{10}$ Kaldı ki Osmanlı Türkçesine giren ve bazıları Türkiye Türkçesinde de kullanılan birçok Arapça ve Farsça kökenli kelime, kelime grubu ve dilsel yapı -biraz önce de belirtildiği gibi- Türkçenin bünyesine uydurulmuş ve artık Türkçeleştirilmiştir.

Bununla beraber Osmanlı Türkçesi tarihi boyunca sadece alıcı bir dil değil, -imparatorluğu yönetenlerin dili olmasının da etkisiyle- güneydoğu Avrupa, Kuzey Afrika, Orta Doğu gibi geniş bir coğrafyadaki bütün dilleri yoğun bir biçimde etkileyen verici bir dil olarak milletler üstü bir nitelik kazanmıştır. Bu durum Osmanlı Türkçesinin toplumun değişik dilsel katmanları arasında bir iletişim aracı olmasi ${ }^{11}$ sonucunu doğurmuştur.

Osmanlı Türkçesini “melez", "yapma bir dil” ve "jargon” terimlerini kullanarak tanımlamaya çalışmak dilbilimsel bakımdan doğru değildir. Çünkü melez dil, örneğin "bisiklet"12 kelimesi

8 Mustafa Özkan, Tarih İçinde Türk Dili (İstanbul: Filiz, 1997), 483.

9 Mustafa Özkan, Tarih İçinde Türk Dili (İstanbul: Filiz, 1997), 87.

10 M.Mehdi Ergüzel "Millı̂ Eğitimde Osmanlı Türkçesinin Seçmeli Ders Olarak Öğretilmesi Üzerine” Turkish Studies, 10, 8 (2015), 38.

11 Nurettin Demir ve Emine Yılmaz, “Türkçenin Tarihi Dönemleri” Türk Dili Yazll Ve Sözlü Anlatım, (Ed. Nurettin Demir, Emine Yılmaz) içinde (Ankara: Nobel, 2013), 48-49; Nurettin Demir ve Emine Y1lmaz, Türk Dili El Kitabl (Ankara: Grafiker, 2016), 93-94.

12 "bi ön eki Latince, siki kelimesi Yunanca, et eki Fransızca, imlâsı ise Türkçedir” (TDK, 2019). 
gibi “ögeleri başka dillerden olan kelime"lerden ${ }^{13}$ oluşmuş dil demektir. Hâlbuki "bisiklet” veya benzeri kelimelerin Türkiye Türkçesinde yaygın olarak kullanılması onu melez bir dil yapmadığı gibi Osmanlı Türkçesinde de bu türden kelimelerin olması Osmanlı Türkçesini melez bir dil yapmaz. Yapma (sun'î) dil ise insan eliyle "sonradan oluşturulmuş"14 doğal olmayan bir dil demektir. Hâlbuki öncesi ve sonrası yazılı belgelerle belli olan Osmanlı Türkçesi, Türkçenin en az beş yüz yıl boyunca kullanılmış tarihî bir döneminin adıdır ve Türkiye Türkçesini doğurmuş olması yönüyle de Türkiye Türkçesi konuşurları açısından oldukça önemlidir. Bu bakımdan Osmanlı Türkçesine yapma dil demek dilbilimsel açıdan doğru olmayacaktır. Jargon ise “aynı meslek veya topluluktaki insanların ortak dilden ayrı olarak kullandıkları özel veya söz dağarcığı" 15 demektir ki beş yüz yıllık tarihi boyunca çok geniş bir coğrafyada sözlü ve yazılı olarak kullanılmış Osmanlı Türkçesinin bir jargon olduğunu iddia etmek bu dönemdeki ortak dilin ne olduğunu veya nasıl adlandırıldığını ve söz konusu mesleğin veya topluluğun adını belirtmek ve bu meslek erbabının ve topluluğun dışındaki insanların kullandıkları dili veya dilleri tanımlamak şartıyla bir anlam kazanacaktır. Nitekim bu yanlış anlamayı engellemek için dil varyasyonları üzerine çalışan bazı araştırmacılar ${ }^{16}$, Osmanlı Türkçesinin sadece fasih Türkçe ile kaba Türkçeden ibaret iki zıt katmandan oluşmadığını, eğitimli kesimin konuşma dili olarak işlev gören orta Türkçe katmanının da var olduğunu ifade etmektedirler.

Eski Anadolu Türkçesi döneminde karşılaştığımız dilsel varyantlar, edebî, dinî ve didaktik işlevleri kısmî olarak yerine getirebilmekte idi. Ancak devletin büyümesi ile yetersiz kalan bu varyantlar yerini klâsik Osmanlı Türkçesine bırakmak zorunda kalmıştır. Uzun tarihi boyunca Türk olmayan unsurların da Osmanlı Türkçesini öğrenmeleri, devletin sınırlarının oldukça genişlemesi ile birlikte iletişim kurduğu farklı toplulukların artması gibi nedenlerle, biraz önce de ifade edildiği gibi, Osmanlı Türkçesi milletler üstü bir iletişim aracı hâline gelmiştir. ${ }^{17}$ Zamanla Klâsik Osmanlı Türkçesini bilmek, konuşmak ve yazmak toplumda, özellikle Türk olmayan unsurlar açısından bir kariyer yapmak, devlet işlerinde görev alabilmek ve prestij sağlamak vb. için doğal ama zorunlu bir husus olarak ortaya çıkmıştır. ${ }^{18}$

Osmanlı Türkçesinin uzun tarihi boyunca divan edebiyatı ile halk edebiyatı arasında kesin sınırlar olmamış, her iki edebiyatta da birbirlerine "öykünen” örneklere rastlanılmıştır. ${ }^{19}$ Konuyla ilgili olarak Levend, Arapça ve Farsça etkisinin ustalık göstermek amacıyla yazılan

13 Türkçe Sözlük (Ankara: Türk Dil Kurumu Yayınları). Erişim 30.10.2019. https://sozluk.gov.tr

14 Türkçe Sözlük (Ankara: Türk Dil Kurumu Yayınları). Erişim 30.10.2019. https://sozluk.gov.tr

15 Türkçe Sözlük (Ankara: Türk Dil Kurumu Yayınları). Erişim 30.10.2019. https://sozluk.gov.tr

16 Örneğin bk. Lars Johanson, Türkisch. Variationstypologie / Variation Typology (2004) içinde. (Ed. Thorsten Roelcke). (Berlin-New York: Walter de Gruyter), 920; Nurettin Demir ve Emine Yılmaz, Türk Dili El Kitabl (Ankara: Grafiker, 2016), 92.

17 Giavonni Molino, İtalyanca-Türkçe Sözlüğü (1641, Roma)'nün ön sözünde Osmanlı İmparatorluğu sınırları içinde elli beş krallık ve beylikte otuz üç millet ve dil bulunduğunu, bunların tümünde de Türkçenin konuşulduğunu belirtmektedir (Tanış, 1989, s. XXXVII'den akt. Develi, 2013, s. 56).

18 Hatta kişilerin devlet nezdindeki makam ve mevki sahibi olabilmeleri onların çoğu zaman şiir ve inşadaki başarıları ve becerilerine göre belirlenmekteydi (Develi, 2013, s. 65).

19 Süer Eker, Çağdaş Türk Dili (Ankara: Grafiker, 2013), 106. 
eserlerde daha çok görüldüğünü, öte yandan sade Türkçenin ${ }^{20}$ konuşma dili ile halk arasında, yazı dili olarak halk için yazılan metinlerde hüküm sürdüğünü belirtmektedir. ${ }^{21}$

Osmanlı Türkçesinin klâsik döneminde özellikle bilim veya resmî işlemlerle ilgili metinlerde Arapça ve Farsçadan çok fazla kelimenin Osmanlı Türkçesinin bünyesine girdiği görülmektedir. Bu durum da Osmanlı Türkçesinin işlev alanlarını önemli ölçüde genişletmiştir. Bununla beraber Arapça ve Farsça ögelerin dile yoğun olarak girmesi Osmanlı Türkçesi yazı dili ile konuşma dili arasındaki farkın oldukça açılmasına da neden olmuştur. Ancak dildeki asıl farkın söz varlığında olduğu, buna karşın dilin iç yapısının (ses, şekil ve cümle yapısının) önemli ölçüde korunduğu söylenebilir²2.

Develi, Osmanlı Türkçesinin özellikle klâsik döneminde yoğun olarak Arapça ve Farsça etkisinde kalmasını, konuşma dili/alt değişke ile yazı dili/üst değişke arasında konuşurların/ yazarların kod değiştirmesi olarak görmektedir. Bu görüşünü değişik metinlerden aldığ ile destekler. Ona göre konuşma dili/halk dili/alt değişke ile yazı dili/üst değişke arasındaki anlaşırlık makasının gittikçe açılmasının sebebi, "Osmanlı aydının yüzyıllar içerisinde, Oğuzların girdikleri kültür ortamının bir zorlaması veya bu kültür ortamının paylaşıldığı diğer dillerle rekabet etme ve bu rekabette yenilmeme arzusu"dur. Ayrıca Arapça ve Farsça ile ilişsileri hiç kopmayan Osmanlı aydınına göre her iki dil de başlangıçtan beri İslam medeniyetinin ortak dilidir. Bu yüzden zaman zaman cennet dili olduğuna dair fetvalar da verdikleri Arapça ve Farsça onlara göre yabancı dil sayılmamıştır. Bu düşünce, yazı dili/üst değişkenin Arapça ve Farsçadan etkilenmesini sorun olarak görmemiştir. ${ }^{23}$

Esasen Osmanlı Türkçesinde -yukarıda nispeten değinmeye çalışıldığı gibi- dönemindeki toplumsal ve kültürel durumlar dolayısıyla her ne kadar özellikle Arapça ve Farsçadan kelime ve terkipler alınsa da dil, özü itibariyle her zaman Türkçe kalmıştır. Çünkü bir cümle istediği kadar yabancı dilin kurallarıyla oluşturulmuş tamlamalar, birleşik sıfatlar, dilbilgisi ögeleriyle dolu olursa olsun, ancak fiili, nesnesi, bağlacı, ${ }^{24}$ söz dizimi, yükleminin aldığı ekler vb. Türkçe ise o dil, yabancı bir dil olarak görülmemelidir. Nitekim sadece Arapça ve/veya Farsça bilen birisi Osmanlı Türkçesini okuyup anlayamaz. Çünkü Osmanlı Türkçesinde Arapça ve Farsçanın belirli bir ölçüde Türkçe ile birleşmesi söz konusudur. ${ }^{25}$ Osmanlı Türkçesini anlamanın olmazsa olmaz şartı Türkçe bilmektir. Çünkü Osmanlı Türkçesi yabancı bir dil değil, özbeöz Türkçedir. Örneğin “Hakimiyet, bilâ-kayd u şart milletindir." cümlesindeki tek Türkçe unsur, yüklemdeki eklerdir. Cümledeki tüm kelimeler ya Arapça ya da Farsçadır. Bu durum, bu cümleyi yabancı dilde oluşturulmuş bir cümle yapmaz. Çünkü bu cümle Türkçe cümle dizilişine uygun ve yüklemi Türkçe eklerle çekimlenmiş olduğundan bu cümleyi Arapça ve/veya Farsça bilen hiç

20 Levend, bunlardan birincisine "Osmanlıca", diğerine ise "Türkçe" demektedir. A.Sırrı Levend, Türk Dilinde Gelişme ve Sadeleşme Evreleri. (Ankara: TDK, 1972), 12.

21 A.Sırrı Levend, Türk Dilinde Gelişme ve Sadeleşme Evreleri. (Ankara: TDK, 1972), 12.

22 Nurettin Demir ve Emine Yllmaz, Türk Dili El Kitabı (Ankara: Grafiker, 2016), 91-94.

23 Hayati Develi, Osmanlı'nın Dili (İstanbul: Kesit, 2013), 59-68.

24 A.Sırrı Levend, Türk Dilinde Gelişme ve Sadeleşme Evreleri. (Ankara: TDK, 1972), 12.

25 F. Kadri Timurtaş, Osmanlı Türkçesi III (İstanbul: Alfa, 2003), XIII-XIV. 
kimse anlayamaz. Dolayısıyla bu cümle sadece Türkçe bilenlerce anlaşılabilir.

Sonuç olarak Osmanlı Türkçesini çok uzun bir tarihî bir geçmişe sahip Türkçenin Eski Anadolu Türkçesinden sonraki, Türkiye Türkçesinden önceki tarihî lehçesi olarak kabul etmek doğru olacaktır. Bu dil, Osmanlı İmparatorluğu'nun hakimiyeti altına giren başta Anadolu olmak üzere, Balkanlar güney Avrupa ve Orta Doğu'dan Kuzey Afrika’ya kadar çok geniş bir coğrafyada değişik dilsel katmanlar arasında bir iletişim aracı olarak kullanılmıştır. Bunun sonucunda İtalyanca, Rumca, Ermenice gibi diller yanında yoğun olarak kendi kültür dairesindeki Arapça ve Farsçadan etkilenmekle birlikte Osmanlı İmparatorluğu'nun hâkim olduğu topraklarda konuşulan bütün dilleri de etkilemiştir. ${ }^{26}$ Osmanlı Türkçesi beş yüz yıldan daha uzun bir süre konuşma ve yazı dili olarak kullanılmıştır. Kütüphanelerimiz bu dil ile dilin hemen bütün kullanım alanlarında üretilmiş binlerce yazma ve basma eser, evrak vb. ile doludur. ${ }^{27}$

Mevcut Osmanlı Türkçesi eğitiminde amaç, tarihe karışmış bu tarihî Türkçeyi diriltmek değil, yüzyıllarca kültür, edebiyat, bilim gibi alanlarda yazılmış geçmiş eserlerimizin tanınması ve onlardan faydalanılmasıdır. ${ }^{28}$ Çünkü bu eserler, günümüzü etkilediği gibi geleceğimize yön vermede de önemli rol oynayacaklardır. Dolayısıyla günümüzü daha doğru anlamlandırıp geleceğimize daha istikametli bir yön verebilmek için geçmişten faydalanmak, bunun için de öncelikle onu iyice öğrenmek gerekmektedir. Geçmişi öğrenmenin en güvenilir yollarından biri de yazılı kaynak metinleri incelemektir.

Bu ve benzeri amaçları kazanmada önemli bir araç olarak Osmanlı Türkçesi dersinin genç nesillere öğretilmesinin oldukça önemli olduğu ileri sürülebilir. Ergüzel'e ${ }^{29}$ göre öğrencileri hiç olmazsa 20. yüzyılın güzel Türkçesi ile yazan en az yüz şair/yazarımızın dilini rahat okur, anlayabilir seviyeye taşımak, Osmanlı Türkçesinin amaçlarından olmalıdır. Dil uzmanlarınca en az elli yıldan beri dile getirilen "dilde yoksunluğun” önlenmesinin bir yolu da budur.

Kaplan, Osmanlı Türkçesi ile yazılmış edebî eserlerin dili dolayısıyla lise müfredat kitaplarından çıkarılmaya çalışılmasının arkasında Batı taklitçiliği ve kendi tarihinden nefret fikri olduğunu belirterek böyle davranaların Batı'nın da cahili olduğunu, çünkü Batılı bilim adamlarının bizim tarih, edebiyat ve sanatımıza bizden daha çok değer verdiklerini ifade etmektedir. Ona göre Osmanlı yazı dilini, Osmanlı mimarîsi, mûsikîsi ve hattı gibi Türkler meydana getirmişlerdir ve bu yazı dili tıpkı diğerleri gibi bir sanat eseridir. ${ }^{30}$

\section{Literatür Taraması}

Osmanlı Türkçesi eğitimi üzerine yapılan tartışmaların geçmişi oldukça yeni sayılabilir. Bu alandaki ilk çalışmaların 15-20 yıllık bir geçmişi olduğu görülmektedir. Bu konudaki çalışmalar Osmanlı Türkçesi dersinin başta sosyal bilimler lisesi olmak üzere bazı liselerde

26 Bu konu hakkında daha geniş bilgi için bk. Günay Karaağaç, Türkçe Verintiler Sözlüğü (Ankara: TDK, 2008).

27 Mustafa Özkan, Osmanlı Türkçesi, TDV İslam Ansiklopedisi, cilt 33, İstanbul: TDV, (2007):483-485

28 F. Kadri Timurtaş, Osmanlı Türkçesi III (İstanbul: Alfa, 2003), XIII.

29 M.Mehdi Ergüzel "Millî Eğitimde Osmanlı Türkçesinin Seçmeli Ders Olarak Öğretilmesi Üzerine” Turkish Studies, 10, 8 (2015), 40.

30 Mehmet Kaplan, Kültür ve Dil (İstanbul: Dergah, 2019), 13-14. 
ders olarak okutulmaya başlanması ile artmaya başlamıştır. Buna rağmen konu ile ilgili yapılan çalışmaların nispeten az olduğu ve daha fazla çalışmalara ihtiyaç duyulduğu söylenebilir.

Literatüre bakıldığında bazı çalışmaların Osmanlı Türkçesi öğretimi üzerine ${ }^{31}$, bazı çalışmaların Osmanlı Türkçesi eğitimi gören öğrencilerin derse ilişkin yaptıkları hatalar ve yanlışlar üzerine ${ }^{32}$, bazı çalışmaların Osmanlı Türkçesi öğretiminde Arapça, Farsça ve Eski Anadolu Türkçesine ait unsurların yeri üzerine ${ }^{33}$, bazı çalışmaların ise lise veya üniversite düzeyindeki öğrencilerin Osmanlı Türkçesi veya Osmanlı Türkçesi dersine ilişkin işlevsellik, programın uygulanışı, istihdamdaki önemi, öğrenen güçlenmesi düzeyleri gibi çeşitli konulardaki görüşleri, tutumları yahut algıları üzerine ${ }^{34}$ yoğunlaştıkları görülmektedir.

Bu çalışmaların sadece Osmanlı Türkçesi ve/veya dersine odaklananların hemen hepsinin katılımcıları, bir veya iki kurum ile sınırlıdır. Verileri açık uçlu sorular ile elde edilmeye çalışılmıştır. Tam bir istatistiksel analize tabi tutulanların sayısı azdır.

Elinizdeki çalışmanın amacı, Türkçe Eğitimi Ana Bilim Dalı lisans öğretim programlarında zorunlu ders olarak okutulan Osmanlı Türkçesi 1 ve Osmanlı Türkçesi 2 derslerinin daha verimli bir şekilde düzenlenmesi, icra edilmesi ve söz konusu derslerdeki akademik başarının artırılması için Türkçe öğretmen adaylarının görüşlerini derleyip yorumlamak ve bu yorumlar 1şığında gerekenlerin yapılması için konunun paydaşlarına önerilerde bulunmaktır.

$\mathrm{Bu}$ konunun alt amaçları ise şunlardır:

1. Türkçe öğretmeni adaylarının Türkçe Eğitimi Ana Bilim Dalı‘nda okutulan Osmanlı Türkçesi 1 ve Osmanlı Türkçesi 2 derslerinin lisans programındaki varlığı, yeri ve gereği hakkındaki düşüncelerini belirlemektir.

2. Türkçe öğretmeni adaylarının Türkçe Eğitimi Ana Bilim Dalı'nda okutulan Osmanlı Türkçesi 1 ve Osmanlı Türkçesi 2 derslerinin bilişsel/akademik gelişimlerine katkısı hakkındaki düşüncelerini belirlemektir.

31 Örnek olarak bk. Şerife Akpınar, "Osmanlı Türkçesi Öğretimi Üzerine”, Journal of International Social Research, 9, 44 (2016), 7-12; Mehmet Ulucan, "Osmanlı Türkçesinin Öğretimi”" Milli Eğitim, 212 (2016), 93-113; M.Mehdi Ergüzel "Millı̂ Eğitimde Osmanlı Türkçesinin Seçmeli Ders Olarak Öğretilmesi Üzerine” Turkish Studies, 10, 8 (2015), 35-42.

32 Mehrali Calp, "Türk Dili ve Edebiyatı Bölümü Öğrencilerinin Osmanlı Türkçesindeki Okuma Hataları Üzerine Bir Çalışma" Uluslararası Türkçe Edebiyat Kültür Eğitim Dergisi (TEKE), 6, 3 (2017), 1679-1705; Mehrali Calp, "Osmanlı Türkçesi Dersini Alan Öğrencilerin Yaptıkları Okuma, Yazma ve Gramer Hatalarının Sebepleri ve Sağaltmaları Üzerine Bir Araştırma” Kastamonu Eğitim Dergisi, 27,4 (2019), 1757-1779.

33 Burhan Baran, "Osmanlı Türkçesi Öğretiminde Arapça, Farsça ve Eski Anadolu Türkçesinin Yeri”" Uluslararası Türkçe Edebiyat Kültür Eğitim Dergisi (TEKE), 7, 4 (2018), 2131-2142.

34 Ahmet Başkan ve Hatice Altunkaya, "Türkçe Öğretmeni Adaylarının Osmanlı Türkçesi Dersine Yönelik Öğrenen Güçlenmesi Düzeyleri” Afyon Kocatepe Üniversitesi Sosyal Bilimler Dergisi, 21, 3 (2019), 808-815; Nihal Çalışkan, "Lise Düzeyindeki Osmanlı Türkçesi Dersi Öğretim Programının Uygulanışına İlişkin Öğrenci Görüşlerine Dayalı Bir Değerlendirme” Bartın Üniversitesi Eğitim Fakültesi Dergisi, 2, 2 (2013), 329-343; Ramazan Kaya, "Tarih Öğretmen Adaylarının Lisans Eğitiminde Osmanlıca Öğretiminin İşlevselliği İle İlgili Görüşleri” Atatürk Üniversitesi Sosyal Bilimler Enstitüsü Dergisi, 17, 2 (2013), 187-206; Bülent Özkan ve N. Kemal Şahbaz, "Türkçe Öğretmeni Adaylarının Alan Derslerinin İşlevselliğine Yönelik Görüşleri” Sakarya University Journal of Education, 1, 1 (2011), 32-43; Necmettin Özmen ve Bilal Yıldırım, "Üniversite Öğrencilerinin Osmanlı Türkçesine İlişkin Tutumları” Dil ve Edebiyat Araştırmaları, 16 (2017), 49-66; Oğuzhan Sevim ve Hatice Bayındır, "Lise Ve Üniversite Öğrencilerinin Osmanlı Türkçesi Dersine Yönelik Görüşlerinin İncelenmesi” Ekev Akademi Dergisi, 20, 67 (2016), 291-302; Malik Yılmaz ve B. Aydemir Şenay, "Türkiye'deki Bilgi ve Belge Yönetimi Bölümlerinin Lisans Ders Programlarında Yer Alan Osmanlı Türkçesi Derslerinin Değerlendirilmesi ve İstihdamdaki Önemi” Atatürk Üniversitesi Sosyal Bilimler Enstitüsü Dergisi, 18, 3 (2014), 1-10. 
3. Türkçe öğretmeni adaylarının Türkçe Eğitimi Ana Bilim Dalı'nda okutulan Osmanlı Türkçesi 1 ve Osmanlı Türkçesi 2 derslerinin duyuşsal gelişimlerine katkısı hakkındaki düşüncelerini belirlemektir.

4. Türkçe öğretmeni adaylarının Türkçe Eğitimi Ana Bilim Dalı'nda okutulan Osmanlı Türkçesi 1 ve Osmanlı Türkçesi 2 derslerinin özgüvenlerine/özgelişimlerine katkısı hakkındaki düşüncelerini belirlemektir.

5. Türkçe öğretmeni adaylarının Türkçe Eğitimi Ana Bilim Dalı'nda okutulan Osmanlı Türkçesi 1 ve Osmanlı Türkçesi 2 derslerinin meslekî gelişimlerine katkısı hakkındaki düşüncelerini belirlemektir.

6. Türkçe öğretmeni adaylarının Türkçe Eğitimi Ana Bilim Dalı'nda okutulan Osmanlı Türkçesi 1 ve Osmanlı Türkçesi 2 derslerinin istihdamlarına/iş bulmalarına katkısı hakkındaki düşüncelerini belirlemektir.

7. Türkçe öğretmeni adaylarının Türkçe Eğitimi Ana Bilim Dalı'nda okutulan Osmanlı Türkçesi 1 ve Osmanlı Türkçesi 2 derslerinin kültür ve tarih duyarlılıklarına katkısı hakkındaki düşüncelerini belirlemektir.

8. Türkçe öğretmeni adaylarının Türkçe Eğitimi Ana Bilim Dalı'nda okutulan Osmanlı Türkçesi 1 ve Osmanlı Türkçesi 2 derslerinin diğer derslere karşı ilgi ve tutumlarına katkısı hakkındaki düşüncelerini belirlemektir.

9. Türkçe öğretmeni adaylarının Türkçe Eğitimi Ana Bilim Dalı’nda okutulan Osmanlı Türkçesi 1 ve Osmanlı Türkçesi 2 derslerinin ders öğretim elemanı ve ders içeriğinin Türkçe öğretmeni adaylarının derse karşı düşüncelerine etkisi hakkındaki düşüncelerini belirlemektir.

10. Türkçe öğretmeni adaylarının Türkçe Eğitimi Ana Bilim Dalı'nda okutulan Osmanlı Türkçesi 1 ve Osmanlı Türkçesi 2 derslerine ilişkin başka düşüncelerini belirlemektir.

\section{Yöntem}

Elinizdeki çalışmada Türkçe Eğitimi Ana Bilim Dalı lisans öğretim programlarında zorunlu ders olarak okutulan Osmanlı Türkçesi 1 ve Osmanlı Türkçesi 2 derslerinin daha verimli bir şekilde düzenlenmesi, icra edilmesi ve söz konusu derslerdeki akademik başarının artırılması için Türkçe öğretmen adaylarının görüşlerini derleyip yorumlamak ve bu yorumlar ışı̆̆ında gerekenlerin yapılması için konunun paydaşlarına önerilerde bulunmak amaçlanmıştır. Bu amacı gerçekleştirmek üzere farklı kurumlardaki mümkün olduğunca fazla katılımcıdan görüş toplanabilmesine özen gösterilmiştir. Bunun için çalışmada anket araştırması yapılmıştır. Araştırmanın ana verileri nicel verilerden elde edilmiştir. Araştırmadaki nitel veriler ise daha çok nicel verileri tamamlayıcı ve doğrulayııı özelliktedir.

\subsection{Araştırma Deseni}

Nicel veriler likert tipinde oluşturulmuş bir anket aracılığıyla edinilmiştir. Bu anketin sonuna anket maddelerinde yer almayan hususlar hakkında katılımcıların görüşlerini belirtebilmeleri için açık uçlu bir kısım eklenmiştir. Çalışmanın nitel verilerine bu açık uçlu kısım aracılığıyla ulaşılmıştır.

Araştırmanın nicel boyutunda betimsel araştırma yöntemlerinden tarama araştırması kullanılmıştır. Tarama araştırması (survey), bir grubun belirli özelliklerini belirlemek için veri 
toplanmasını amaçlayan bir araştırma yöntemidir. Tarama araştırmalarında çeşitli anket teknikleri ile hazırlanan sorular katılımcılara bizzat görüşerek ya da e-posta, telefon gibi teknolojik haberleşme yöntemleri kullanılarak ulaştırılır. Alınan cevaplar daha sonra cevaplayan kişilere ait sıklık dereceleri ve yüzdeler (frekans) şeklinde bir tablo hâline getirilir ve raporlaştırılır. ${ }^{35}$

Araştırmanın nitel boyutunda ise olgubilim (fenomonoloji) araştırması kullanılmıştır. Olgubilim, genellikle varlığı bilinen ancak derinlemesine bir anlayışa sahip olunmayan olgulara odaklanır. Olgubilim, bir olgunun daha iyi anlaşılmasına yardımcı olduğundan bilimsel çalışmalara katkıda bulunmaktadır. ${ }^{36}$

\subsection{Katılımcilar}

Araştırmanın katılımcıları gönüllülük esasına göre amaçlı örneklem yoluyla seçilmiştir. Katılımcılar 15 farklı üniversitenin Türkçe Eğitimi Ana Bilim Dalı’nda Osmanlı Türkçesi 1 ve Osmanlı Türkçesi 2 dersini almış ikinci, üçüncü ve dördüncü sınıflarda öğrenim görmekte olan 277 Türkçe öğretmeni adayından oluşmaktadır. Katılımcıların farklı kurumlardan olması, katılımcıların demografik çeşitliliğini artıracağı gibi öğretim elemanı, dersin işlenişi, dersteki metinlerin türü ve düzeyi gibi konulardaki etkilerin öğrencilerin düşüncelerini etkilemedeki oranını düşürecektir. Nitekim bu çalışmada katılımcıların \%69,3 (n=192)'üü ögretim elemanının meslekî ve pedagojik yeterliliğinin, \%71,4 (n=198)'i de derste okutulan metin türlerinin, konularının ve düzeylerinin düşüncelerini etkilediğini belirtmektedir.

Tablo 1'de katılımcılarn cinsiyet kategorisi listelenmiştir.

Tablo 1: Katılımciların cinsiyet kategorisi

\begin{tabular}{lcc}
\hline Cinsiyet & (\%) & n \\
\hline Kuz & 78,3 & 217 \\
Erkek & 21,7 & 60 \\
Toplam & 100 & 277 \\
\hline
\end{tabular}

Tablo 1'de görüldüğü üzere katılımcıların büyük çoğunluğu kızlardan oluşmaktadır.

Tablo 2'de katılımcıların mensup olduğu üniversiteler listelenmiştir.

Tablo 2: Katılımcıların mensup olduğu üniversiteler

\begin{tabular}{lcc}
\hline Üniversiteler & $\mathbf{\%}$ & $\mathbf{n}$ \\
\hline Erzincan Binali Yıldırım Üniversitesi & 28,51 & 79 \\
Yıldız Teknik Üniversitesi & 24,54 & 68 \\
Niğde Ömer Halisdemir Üniversitesi & 22,74 & 63 \\
Diğer* & 24,18 & 67 \\
Toplam & 100 & 277 \\
\hline
\end{tabular}

* (Azalan sırayla) Aksaray, Artvin Çoruh, İstanbul Sabahattin Zaim, Tokat Gaziosmanpaşa, Marmara, Sinop, Van Yüzüncü Yıl, Uludağ, Girne Amerikan, İstanbul-Cerrahpaşa, Adıyaman, Kilis 7 Aralık üniversiteleri.

35 Şener Büyüköztürk vd., Eğitimde Bilimsel Araştırma Yöntemleri (Ankara: Pegem Akademi, 2018), 15.

36 Ali Yıldırım ve Hasan Şimşek, Sosyal Bilimlerde Araştırma Yöntemleri (8. baskı). (Ankara: Seçkin, 2011), 72-75. 
Tablo 2'de görüldüğü gibi çalışmaya en çok Erzincan Binali Yıldırım, Yıldız Teknik ve Niğde Ömer Halisdemir üniversitelerinden katılım sağlanmıştır. Bu üç üniversite dışında 12 değişik üniversiteden de farklı oranlarda katılımın olduğu görülmektedir.

\subsection{Verilerin Toplanması}

Bu çalışmada Türkçe öğretmeni adaylarının Türkçe Eğitimi Ana Bilim Dalı lisans öğretim programında birinci ve ikinci yarıyılda haftada ikişer saat olmak üzere zorunlu olarak okutulan Osmanlı Türkçesi 1 ve Osmanlı Türkçesi 2 dersi ile ilgili görüşlerinin tespit edilmesi amaçlanmıştır. Katılımcılara google dokümanlar aracılığıyla online ortamda likert tipinde hazırlanmış bir anket formu uygulanmıştır. Formun sonunda açık uçlu bir madde ile katılımcıların konu ile ilgili diğer görüş ve düşüncelerini ifade edebilmelerine de imkân tanınmıştır. Araştırmadaki veriler 2019 yılında toplanmış ve kullanılmıştır.

Google dokümanlar üzerinden online ortamda oluşturulan bu formda 9 farklı kategoriye ayrılmış toplam 35 madde yer almaktadır. Form üzerinde yapılan ayarlama ile her birey formu yalnızca bir kez doldurabilmektedir. Bireylere formu doldurduktan sonra otomatik olarak bir bilgilendirme e-postası gönderilmektedir. Katılımc1, isterse bu e-postada yer alan linki kullanarak görüşlerini güncelleme imkanına da sahiptir. Katılımcılardan bu formun bir hafta içinde müsait oldukları bir zaman diliminde doldurmaları istenmiştir. Bir hafta sonra form katılımcılara kapatılmış ve verilerin son hâline ulaştı̆̆ kabul edilmiştir. Çalışmada ulaşılan bulgular bu veriler üzerinden edinilmiştir.

Katılımcıların Türkçe Eğitimi Ana Bilim Dalı'nda okutulan Osmanlı Türkçesi 1-2 derslerinin lisans programındaki varlığ , yeri ve gereği (6 madde), bilişsel/akademik gelişimlerine (9 madde), duyuşsal gelişimlerine (4 madde), özgüven/özgelişimlerine (3 madde), meslekî gelişimlerine (4 madde), istihdamlarına/iş bulmalarına (1 madde), kültür ve tarih duyarlılıklarına ilişkin gelişimlerine (2 madde), diğer derslere karşı ilgi ve tutumlarına ilişkin gelişimlerine (4 madde) katkısına ilişkin görüşleri ile ders öğretim elemanı ve ders içeriğgine ilişkin (2 madde) düşünceleri toplam 35 madde belirlenmeye çalışılmıştır. Anketin sonundaki açık uçlu kısım aracılığıyla katılımcıların konu ile ilgili diğer düşüncelerinin tespit edilmesi amaçlanmıştır. Anket formundaki maddelerin oluşturulması için ilgili literatür ve lise ve üniversite Osmanlı Türkçesi dersleri öğretim programları taranmıştır. Tarama sonrasında ölçme aracının madde havuzu oluşturulmuş, daha sonra oluşturulan maddeler kendi içinde benzer niteliklerine göre sınıflandırılmıştır. Ölçekteki her maddeye cevap olarak beş seçenek verilmiştir: kesinlikle katılıyorum, katılıyorum, kararsızım, katılmıyorum, kesinlikle katılmıyorum.

\subsection{Verilerin Analizi}

Anket formundaki veriler, betimsel analiz yöntemine göre analiz edilmiştir.

Anket uygulandıktan sonra toplanan nicel veriler SPSS 22 istatistik paket programı aracılığıyla analiz edilmiştir. Ölçeğin güvenirlik çalışması yapılmış ve Cronbach Alpha 
değeri. 96 olarak bulunmuştur. Buna göre ölçek güvenilir sayılabilir. Ankette ölçek aracılığıyla toplanmış değişkenler bulunmadığından nicel verileri oluşturan her bir maddenin sadece sıklık ve yüzdeleri hesaplanmıştır. Çalışmanın bulguları sunulurken, "kesinlikle katılıyorum" ve "katılıyorum" önermeleri, "katılıyorum" başlığı altında bir arada ve "katılmıyorum" ve "kesinlikle katılmıyorum" önermeleri de "katılmıyorum" başlı̆̆ı altında bir arada hesaplanıp değerlendirmeye alınmıştır. "kararsızım" ifadesi ise tek başına değerlendirilmiştir.

Anket maddelerinin oluşturulması ve sınıflandırılması konusundaki geçerlik ve güvenirliğin sağlanması amacıyla hazırlanan anket formu, konu ile ilgili daha önce yayın yapmış alanında uzman iki öğretim üyesine sunulmuştur. Alan uzmanı öğretim üyelerinin değerlendirmelerini daha sağlıklı yapabilmeleri için araştırmacı tarafından hazırlanmış uzman değerlendirme formu da alan uzmanlarına gönderilmiştir. Uzman değerlendirme formu her bir madde için "uygun”, "uygun değil", "geliştirilmeli" ve "açıklamalar" bölümlerini içeren bir formdur. Uzmanlar ile beş maddede görüş ayrılığı olmuş, bunlardan ikisinde araştırmacı ile uzmanlar görüş birliğine varabilmişlerdir. Ortaya çıkan sonuç, Miles ve Huberman ${ }^{37}$ tarafından geliştirilen kodlayıcılar arası güvenirlik testi formülü (Güvenirlik=Görüş birliği/görüş birliği+görüş ayrılığı) ile test edilmiştir. Çalışmamızdaki kodlayıcılar arası güvenirlik oranı (Güvenirlik=32/32+3) .91 olarak hesaplanmıştır. Miles ve Huberman'a göre araştırmacı ile uzmanlar arasındaki uyumluluk oranı \%90'a yakın ya da \%90'dan fazla ise çalışmanın güvenirliği istenen düzeyde demektir. Buna göre çalışmamızın maddeleri ve sınıflandırma işlemi güvenilir olarak değerlendirilmiştir. Uzman görüşlerine göre güncellenen anket formu için önce bir pilot çalışma yapılmıştır. Buradan alınan görüşlere ve gözlemlere göre anket formuna son şekli verilmiştir.

Bu çalışmada sonuçların geçerliğini sağlamak amacıyla çalışmanın nitel veri analiz süreci ayrıntılı bir şekilde açıklanmıştır. Nitel verilerin analizinde bulgular yorumlanırken katılımcılardan direkt alıntılara yer verilerek varılan sonuçların güvenirliliğin artırılması amaçlanmıştır.

Türkçe öğretmeni adaylarının Türkçe Eğitimi Ana Bilim Dalı lisans öğretim programlarında zorunlu ders olarak okutulan Osmanlı Türkçesi 1 ve Osmanlı Türkçesi 2 dersleri hakkındaki görüşlerinin tespit edilmesini amaçlayan bu çalışma, nicel ve nitel veriler toplanarak gerçekleştirilmiştir. Verilerin farklı ölçme araçlarından daha detaylı ve doğrulanabilir olarak elde edilebilmesi için bu çalışmada karma yönteme başvurulmuştur.

\section{Bulgular}

Çalışmada Türkçe öğretmen adaylarının lisans düzeyindeki Osmanlı Türkçesi 1 ve Osmanlı Türkçesi 2 dersleri hakkındaki görüşleri 9 farklı kategoride toplam 35 madde ile belirlenmeye çalışılmıştır. Formun en sonunda da katılımcılara formdaki maddeler haricinde ayrıca belirtmek istedikleri düşünceleri varsa bunları da yazmaları istenmiştir. Böylece katılımcıların formda belirtilmeyen konulardaki düşüncelerinin de tespit edilmesi amaçlanmıştır.

37 Matthew B. Miles, ve A. Michael Huberman Qualitative data analysis: An expanded Sourcebook. (2nd ed). (Thousand Oaks, CA: Sage, 1994), 64. 
Şekil 1'de Türkçe öğretmen adaylarının lisans düzeyindeki Osmanlı Türkçesi 1 ve Osmanlı Türkçesi 2 dersi hakkındaki görüşlerinin tespit edilmesini için oluşturulan kategoriler ve madde sayıları listelenmiştir.

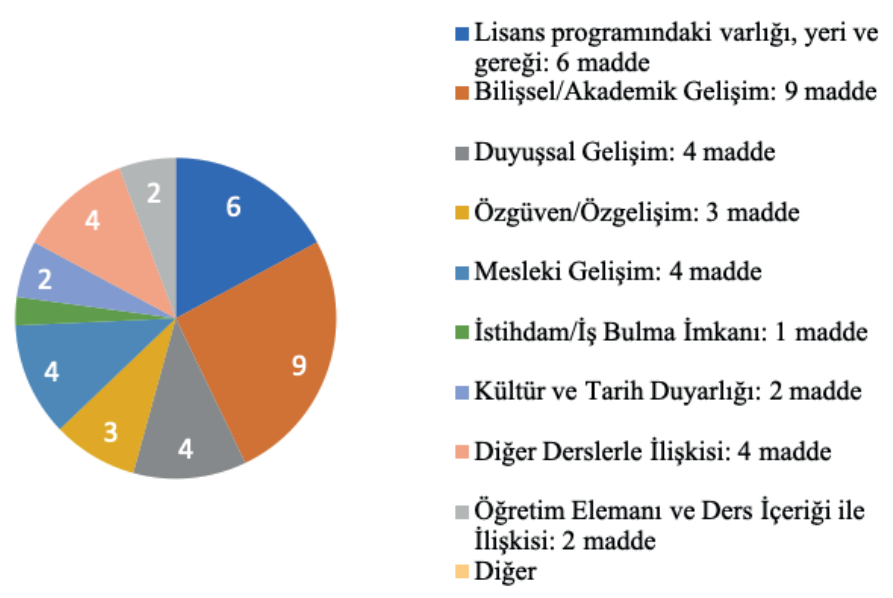

Şekil 1: Türkçe öğretmen adaylarının lisans düzeyindeki Osmanlı Türkçesi 1 ve Osmanlı Türkçesi 2 dersi hakkındaki görüşlerinin tespit edilmesini için oluşturulan kategoriler ve madde sayıları (Toplam 35 madde)

Türkçe öğretmeni adaylarının Osmanlı Türkçesi 1 ve Osmanlı Türkçesi 2 dersinin Türkçe Eğitimi Ana Bilim Dalı lisans programındaki varlığı, yeri ve gereği hakkındaki düşünceleri

Bu kategorilerden birincisi Türkçe öğretmen adaylarının Osmanlı Türkçesi 1 ve Osmanlı Türkçesi 2 derslerinin Türkçe Eğitimi Ana Bilim Dalı lisans öğretim programındaki varlığg, yeri ve gereği hakkındaki düşüncelerinin ne olduğunu tespit etmeyi amaçlamaktadır.

Tablo 3'de Türkçe öğretmeni adaylarının Osmanlı Türkçesi 1 ve Osmanlı Türkçesi 2 dersinin Türkçe Eğitimi Ana Bilim Dalı lisans programındaki varlığı, yeri ve gereği hakkındaki düşüncelerine yer verilmiştir. 
Tablo 3: Türkçe öğretmeni adaylarının Osmanlı Türkçesi 1 ve Osmanlı Türkçesi 2 dersinin Türkçe Eğitimi Ana Bilim Dalı lisans programındaki varlığı, yeri ve gereği hakkındaki düşünceleri

\begin{tabular}{|c|c|c|c|c|c|c|}
\hline & \multicolumn{2}{|c|}{ Katıllyorum } & \multicolumn{2}{|c|}{ Katılmıyorum } & \multicolumn{2}{|c|}{ Kararsızım } \\
\hline & $\%$ & $\mathbf{n}$ & $\%$ & $\mathbf{n}$ & $\%$ & $\mathbf{n}$ \\
\hline $\begin{array}{l}\text { Osmanlı Türkçesi 1-2 derslerinin Türkçe eğitimi Ana Bilim } \\
\text { Dalı'nın amaçlarına uygun bir ders olduğunu düşünüyorum. }\end{array}$ & 60,7 & 168 & 27,1 & 75 & 12,3 & 34 \\
\hline $\begin{array}{l}\text { Osmanlı Türkçesi 1-2 dersinin beklentilerimi karşıladığını } \\
\text { düşünüyorum. }\end{array}$ & 49,1 & 136 & 29,2 & 81 & 21,7 & 60 \\
\hline $\begin{array}{l}\text { Osmanlı Türkçesi dersi 1-2, Türkçe eğitimi bölümlerinde } \\
\text { iki yarıyıl haftada ikişer saat olarak okutulmaktadır. Türkçe } \\
\text { ögretmeni adayları açısından Osmanlı Türkçesi ders süresinin } \\
\text { yeterli olduğunu düşünüyorum. }\end{array}$ & 55,9 & 155 & 26,4 & 83 & 17,7 & 49 \\
\hline $\begin{array}{l}\text { Osmanlı Türkçesi 1-2 ders içeriğindeki bilgilerin meslekî bilgi } \\
\text { bakımından bir Türkçe öğretmeni adayı için yeterli olduğunu } \\
\text { düşünüyorum. }\end{array}$ & 54,9 & 152 & 27,4 & 76 & 17,7 & 49 \\
\hline $\begin{array}{l}\text { Osmanlı Türkçesi 1-2 dersi Türkçe eğitimi lisans programında } \\
\text { 1. sınıfta yer almaktadır. Bu dersin ileriki (2, } 3 \text { veya } 4 .) \\
\text { sinıflarda öğretilmesinin daha doğru olacağını düşünüyorum. }\end{array}$ & 30,4 & 84 & 53,8 & 149 & 15,9 & 44 \\
\hline $\begin{array}{l}\text { Osmanlı Türkçesi 1-2 dersinin Türkçe eğitimi lisans } \\
\text { programında zorunlu bir derstir. Bu dersin seçmeli olması } \\
\text { gerektiğini düşünüyorum. }\end{array}$ & 43,3 & 120 & 45,1 & 125 & 11,6 & 32 \\
\hline
\end{tabular}

Tablo 3'de de görüldüğü üzere katılımcıların yarısından çoğu Osmanlı Türkçesi dersinin Türkçe eğitimi Ana Bilim Dalı'nın amaçlarına uygun bir ders olduğunu, programdaki ders süresinin yeterli olduğunu, bu ders kapsamında verilen bilgilerin kendileri için yeterli olduğunu ve bu dersin mevcut programda uygulanageldiği üzere birinci sınıfta verilmesinde herhangi bir sakınca görmediklerini belirtmişlerdir. Mevcut programda zorunlu bir ders olan Osmanlı Türkçesi derslerinin seçmeli olması gerektiğini düşünenlerin oranı ile zorunlu olarak kalması gerektiğini düşünenlerin oranı arasındaki fark, seçmeli olması gerektiğini düşünenler lehine \%1,8'dir. Katılımcıların hemen hemen yarısı dersin beklentilerini karşıladığını düşünmektedir. Beklentilerinin karşılanmadığını düşünenlerin oranı ise \%29,2 ile düşük sayılabilir. Tüm maddelere ilişkin kararsızların oranı \%11,6 ile \%21,7 arasındadır.

\section{Osmanlı Türkçesi 1 ve Osmanlı Türkçesi 2 dersinin Türkçe öğretmeni adaylarının} bilişsel/akademik gelişimlerine etkisi hakkındaki düşünceleri

Bu çalışmada Osmanlı Türkçesi 1 ve Osmanlı Türkçesi 2 derslerinin Türkçe öğretmeni adaylarının bilişsel/akademik gelişimlerine etkisi hakkındaki düşüncelerinin ne olduğu anlaşılmaya çalışılmıştır.

Tablo 4 'de Osmanlı Türkçesi 1 ve Osmanlı Türkçesi 2 dersinin Türkçe öğretmeni adaylarının bilişsel/akademik gelişimlerine etkisi hakkındaki düşüncelerine yer verilmiştir. 
Tablo 4: Osmanlı Türkçesi 1 ve Osmanlı Türkçesi 2 dersinin Türkçe öğretmeni adaylarının bilişsel/ akademik gelişimlerine etkisi hakkındaki düşünceleri

\begin{tabular}{|c|c|c|c|c|c|c|}
\hline & \multicolumn{2}{|c|}{ Katılıyorum } & \multicolumn{2}{|c|}{ Katılmıyorum } & \multicolumn{2}{|c|}{ Kararsızım } \\
\hline & $\%$ & $\mathbf{n}$ & $\%$ & $\mathrm{n}$ & $\%$ & $\mathbf{n}$ \\
\hline $\begin{array}{l}\text { Osmanlı Türkçesi 1-2 dersinin akademik başarımın artmasına } \\
\text { katkıda bulunduğunu düşünüyorum. }\end{array}$ & 52 & 144 & 31,4 & 87 & 16,6 & 46 \\
\hline $\begin{array}{l}\text { Osmanlı Türkçesi dersi } 1-2 \text { kapsamında edindiğim bilgi ve } \\
\text { becerilerin Türk dili (Türkçe) hakkındaki bilgilerimi artırdığına } \\
\text { ve dil bilincimin gelişmesine katkıda bulunduğuna inanıyorum. }\end{array}$ & 59,9 & 166 & 23,8 & 66 & 16,2 & 45 \\
\hline $\begin{array}{l}\text { Osmanlı Türkçesi 1-2 dersinin kelime hazinemin artmasına } \\
\text { katkıda bulunduğunu düşünüyorum. }\end{array}$ & 67,6 & 187 & 21,3 & 59 & 11,2 & 31 \\
\hline $\begin{array}{l}\text { Osmanlı Türkçesi 1-2 dersinin okuduğunu anlama düzeyimin } \\
\text { gelişmesine katkıda bulunduğunu düşünüyorum. }\end{array}$ & 51,3 & 142 & 29,6 & 82 & 19,1 & 53 \\
\hline $\begin{array}{l}\text { Osmanlı Türkçesi 1-2 dersinin yazma becerimin gelişmesine } \\
\text { katkıda bulunduğunu düşünüyorum. }\end{array}$ & 49,5 & 137 & 30,3 & 84 & 20,2 & 56 \\
\hline $\begin{array}{l}\text { Osmanlı Türkçesi 1-2 dersinin dinleme becerimin gelişmesine } \\
\text { katkıda bulunduğunu düşünüyorum. }\end{array}$ & 36,8 & 102 & 39 & 108 & 24,2 & 67 \\
\hline $\begin{array}{l}\text { Osmanlı Türkçesi 1-2 dersinin konuşma becerimin gelişmesine } \\
\text { katkıda bulunduğunu düşünüyorum. }\end{array}$ & 37,6 & 104 & 41,6 & 115 & 20,9 & 58 \\
\hline $\begin{array}{l}\text { Osmanlı Türkçesi 1-2 dersi sayesinde Arapça ve Farsça ile ilgili } \\
\text { bilgilerimin arttığını düşünüyorum. }\end{array}$ & 68,3 & 189 & 17,7 & 49 & 14,1 & 39 \\
\hline $\begin{array}{l}\text { Osmanlıca 1-2 dersinde öğrendiklerimin farklı alanlara ilgi } \\
\text { duymamı sağladığını düşünüyorum. }\end{array}$ & 48,4 & 134 & 32,5 & 90 & 19,1 & 53 \\
\hline
\end{tabular}

Tablo 4'de de görüldüğü üzere katılımcıların büyük çoğunluğu Osmanlı Türkçesi 1-2 dersi sayesinde Arapça ve Farsça ile ilgili bilgilerinin ve kelime hazinelerinin arttığını düşünmektedirler. Osmanlı Türkçesi dersi 1-2 kapsamında edindiği bilgi ve becerilerin Türkçe hakkındaki bilgilerini artırdığına ve dil bilinçlerinin gelişmesine katkıda bulunduğuna inananların oranı da oldukça yüksektir. Yine katılımcıların yarıdan biraz fazlası Osmanlı Türkçesi 1-2 dersinin akademik başarımın artmasına katkıda bulunduğunu ve okuduğunu anlama düzeylerinin gelişmesine katkıda bulunduğunu beyan etmişlerdir. Osmanlı Türkçesi 1-2 dersinin yazma becerimin gelişmesine katkıda bulunduğunu ve Osmanlıca 1-2 dersinde öğrendiklerinin farklı alanlara ilgi duymasını sağladığını düşünenlerin oranı da yarıya yakındır. Buna karşın Osmanlı Türkçesi 1-2 dersinin dinleme ve konuşma becerilerinin gelişmesine katkıda bulunduğunu düşünenlerin oranı yaklaşık \% 36-37 ile düşük sayılabilir. Osmanlı Türkçesi dersinin dinleme ve konuşma becerilerinin gelişmesine herhangi bir katkıda bulunmadığını düşünenler ile bu görüşe katılmayan arasındaki fark, bu dersin dinleme ve konuşma becerilerinin gelişmesine katkıda bulunmadığını düşünenler lehine \%2-4 arasındadır. Bu iki maddedeki kararsızların oranının diğer maddelerdeki kararsızlara göre daha yüksek olması dikkati çekmektedir. Tüm maddelere ilişkin kararsıların oranı \%11,2 ile \%24,2 arasındadır. 


\section{Osmanlı Türkçesi 1 ve Osmanlı Türkçesi 2 dersinin Türkçe öğretmeni adaylarının duyuşsal gelişimlerine etkisi hakkındaki düşünceleri}

Bu çalışmada Osmanlı Türkçesi 1 ve Osmanlı Türkçesi 2 derslerinin Türkçe öğretmeni adaylarının bilişsel/akademik gelişimlerine etkisi hakkındaki düşüncelerinin ne olduğu anlaşılmaya çalışılmıştır.

Tablo 5'de Türkçe öğretmeni adaylarının Osmanlı Türkçesi 1 ve Osmanlı Türkçesi 2 dersinin Türkçe öğretmeni adaylarının duyuşsal gelişimlerine etkisi hakkındaki düşüncelerine yer verilmiştir.

Tablo 5: Türkçe öğretmeni adaylarının Osmanlı Türkçesi 1 ve Osmanlı Türkçesi 2 dersinin Türkçe öğretmeni adaylarının duyuşsal gelişimlerine etkisi hakkındaki düşünceleri

\begin{tabular}{|c|c|c|c|c|c|c|}
\hline & \multicolumn{2}{|c|}{ Katılıyorum } & \multicolumn{2}{|c|}{ Katılmıyorum } & \multicolumn{2}{|c|}{ Kararsızım } \\
\hline & $\%$ & $\mathbf{n}$ & $\%$ & $\mathbf{n}$ & $\%$ & $\mathbf{n}$ \\
\hline $\begin{array}{l}\text { Osmanlı Türkçesi 1-2 dersinin millî duygularımın gelişmesine } \\
\text { katkıda bulunduğunu düşünüyorum. }\end{array}$ & 49,8 & 148 & 29,6 & 82 & 20,6 & 57 \\
\hline $\begin{array}{l}\text { Osmanlı Türkçesi 1-2 dersi kapsamına Osmanlı Türkçesi ile } \\
\text { yazılmış metinleri okurken duygusal coşkunluk yaşadığımı ve } \\
\text { heyecanlandığımı hissediyorum. }\end{array}$ & 41,5 & 105 & 36,4 & 101 & 22 & 61 \\
\hline $\begin{array}{l}\text { Türkçe öğretmeni adayı olarak Osmanlı Türkçesi dersine ilişkin } \\
\text { duygu, tutum ve düşüncelerimin genel olarak olumlu olduğunu } \\
\text { söyleyebilirim. }\end{array}$ & 62,3 & 167 & 22,8 & 63 & 17 & 47 \\
\hline $\begin{array}{l}\text { Osmanlı Türkçesi 1-2 dersi kapsamında yapmış olduğumuz } \\
\text { etkinliklerin benim açımdan anlamlı olduğunu düşünüyorum. }\end{array}$ & 59,9 & 166 & 24,2 & 67 & 15,9 & 44 \\
\hline
\end{tabular}

Tablo 5'e göre katılımcıların büyük çoğunluğu Türkçe öğretmeni adayı olarak Osmanlı Türkçesi dersine karşı duygu, tutum ve düşünce açısından genel olarak olumlu bir görüşe sahip olduklarını ve bu ders kapsamında yapmış oldukları etkinliklerin veya çalışmaların kendileri için anlamlı olduğunu belirtmişlerdir. Katılımcıların yarıya yakını dersin millî duygularının gelişmesine katkıda bulunduğunu düşünmektedirler. Osmanlı Türkçesi 1-2 dersi kapsamında Osmanlı Türkçesi ile yazılmış metinleri okurken duygusal coşkunluk yaşadığınıı ve heyecanlandığını hissedenlerin oranı ile bu görüşe katılmayanların oranı arasında birinciler lehine yaklaşık \%5'lik bir fark vardır. Tablodaki birinci ve ikinci maddelerdeki kararsızların oranının diğer maddelerdeki kararsızların oranına göre daha fazla olması dikkat çekicidir. Burada birinci ve ikinci maddedeki görüşe katılanların oranının beklenenden nispeten daha düşük olduğu söylenebilir. Tüm maddelere ilişskin kararsıların oranı \%15,9 ile \%22 arasındadır.

Osmanlı Türkçesi 1 ve Osmanlı Türkçesi 2 dersinin Türkçe öğretmeni adaylarının özgüvenleri/özgelişimlerine etkisi hakkındaki düşünceleri

Bu çalışmada Osmanlı Türkçesi 1 ve Osmanlı Türkçesi 2 derslerinin Türkçe öğretmeni adaylarının özgüvenleri/özgelişimlerine etkisi hakkındaki düşüncelerinin ne olduğu anlaşılmaya çalışılmıştır. 
Tablo 6'da Türkçe öğretmeni adaylarının Osmanlı Türkçesi 1 ve Osmanlı Türkçesi 2 dersinin Türkçe öğretmeni adaylarının özgüvenleri/özgelişimlerine gelişimlerine etkisi hakkındaki düşüncelerine yer verilmiştir.

Tablo 6: Türkçe öğretmeni adaylarının Osmanlı Türkçesi 1 ve Osmanlı Türkçesi 2 dersinin Türkçe öğretmeni adaylarının özgüvenleri/özgelişimlerine gelişimlerine etkisi hakkındaki düşünceleri

\begin{tabular}{|c|c|c|c|c|c|c|}
\hline & \multicolumn{2}{|c|}{ Katılıyorum } & \multicolumn{2}{|c|}{ Katılmıyorum } & \multicolumn{2}{|c|}{ Kararsızım } \\
\hline & $\%$ & $\mathbf{n}$ & $\%$ & $\mathbf{n}$ & $\%$ & $\mathbf{n}$ \\
\hline Osmanlı Türkçesi konusunda yeterli olduğumu düşünüyorum. & 37,9 & 105 & 37,2 & 103 & 24,9 & 69 \\
\hline $\begin{array}{l}\text { Osmanlı Türkçesi 1-2 dersinin keyifli bir ders olduğunu } \\
\text { düşünüyorum. }\end{array}$ & 54,6 & 151 & 25,7 & 61 & 19,9 & 55 \\
\hline $\begin{array}{l}\text { Osmanlı Türkçesi 1-2 dersinin öğrenmesi kolay bir ders } \\
\text { olduğunu düşünüyorum. }\end{array}$ & 38,2 & 106 & 41,8 & 116 & 19,9 & 55 \\
\hline
\end{tabular}

Tablo 6' da da görüldüğü gibi katılımcıların yarıdan fazlası Osmanlı Türkçesi dersini keyifli bulmaktadır. Buna karşın kendilerini ders konusunda yeterli bulanların oranı nispeten düşüktür. Ders konusunda kendilerini yeterli bulanlar ile yeterli bulmayanların oranı arasındaki fark, yeterli bulanların lehine \%0,7'dir. Bu maddede kararsız olanların oranı ise nispeten yüksektir. Dersin kolay olmadığını düşünenlerin oranı bu görüşe katılmayanların oranı arasındaki fark, kolay olmadığını düşünenlerin lehine \%3,6'dır. Dersi kolay bulanların oranının da nispeten düşük olduğu görülmektedir. Tüm maddelere ilişkin kararsızların oranı $\% 19,9$ ile $\% 24,9$ arasindadir.

\section{Osmanlı Türkçesi 1 ve Osmanlı Türkçesi 2 dersinin Türkçe öğretmeni adaylarının meslekî gelişimlerine etkisi hakkındaki düşünceleri}

Bu çalışmada Osmanlı Türkçesi 1 ve Osmanlı Türkçesi 2 derslerinin Türkçe öğretmeni adaylarının meslekî gelişimlerine etkisi/katkısı hakkındaki düşüncelerinin ne olduğu anlaşılmaya çalışılmıştır.

Tablo 7'de Türkçe öğretmeni adaylarının Osmanlı Türkçesi 1 ve Osmanlı Türkçesi 2 dersinin Türkçe öğretmeni adaylarının meslekî gelişimlerine etkisi hakkındaki düşüncelerine yer verilmiştir. 
Tablo 7: Türkçe öğretmeni adaylarının Osmanlı Türkçesi 1 ve Osmanlı Türkçesi 2 dersinin Türkçe öğretmeni adaylarının meslekî gelişimlerine etkisi hakkındaki düşünceleri

\begin{tabular}{lcccccc}
\hline & \multicolumn{3}{c}{ Katılıyorum } & \multicolumn{2}{c}{ Katılmıyorum } & \multicolumn{2}{c}{ Kararsızım } \\
\cline { 2 - 7 } & $\mathbf{\%}$ & $\mathbf{n}$ & $\mathbf{\%}$ & $\mathbf{n}$ & $\mathbf{\%}$ & $\mathbf{n}$ \\
\hline $\begin{array}{l}\text { Osmanlı Türkçesi 1-2 dersi kapsamında edindiğim bilgi } \\
\text { ve becerilerin meslekî hayatıma katkıda bulunacağııı } \\
\text { düşünüyorum. }\end{array}$ & 53,8 & 149 & 28,9 & 80 & 17,3 & 48 \\
$\begin{array}{l}\text { Osmanlı Türkçesi 1-2 dersinin okuma ve yazma } \\
\text { alışkanlıklarımın gelişmesine katkıda bulunduğunu } \\
\text { düşünüyorum. }\end{array}$ & 48,4 & 134 & 32,5 & 90 & 19,1 & 53 \\
$\begin{array}{l}\text { Osmanlı Türkçesi 1-2 dersinin meslekî özgüvenimin artmasına } \\
\text { katkıda bulunduğunu düşünüyorum. }\end{array}$ & 50,9 & 141 & 31 & 86 & 18,1 & 50 \\
$\begin{array}{l}\text { Osmanlı Türkçesi 1-2 dersinin meslekî merakımın artmasına } \\
\text { katkıda bulunduğunu düşünüyorum. }\end{array}$ & 48,3 & 134 & 31,4 & 87 & 20,2 & 56 \\
\hline
\end{tabular}

Tablo 7'de de görüleceği üzere katılımcıların yarıdan fazlası Osmanlı Türkçesi dersi kapsamında edindikleri bilgi ve becerilerin meslekî hayatlarına ve meslekî özgüvenlerinin artmasına katkıda bulunduğunu düşünmektedir. Katılımcıların yarıya yakını ise Osmanlı Türkçesi okuma ve yazma alışkanlıklarının gelişmesine ve meslekî meraklarının artmasına katkıda bulunduğunu beyan etmektedirler. Tablodaki tüm maddelere ilişkin kararsızların oranı $\% 17,3$ ile $\% 20,2$ arasindadir.

Osmanlı Türkçesi 1 ve Osmanlı Türkçesi 2 dersinin Türkçe öğretmeni adaylarının istihdam/iş bulmalarına etkisi hakkındaki düşünceleri

Bu çalışmada Osmanlı Türkçesi 1 ve Osmanlı Türkçesi 2 derslerinin Türkçe öğretmeni adaylarının istihdam/iş bulmalarına etkisi hakkındaki düşüncelerinin ne olduğu anlaşılmaya çalışılmıştır.

Tablo 8'de Türkçe öğretmeni adaylarının Osmanlı Türkçesi 1 ve Osmanlı Türkçesi 2 dersinin Türkçe öğretmeni adaylarının istihdam/iş bulmalarına etkisi hakkındaki düşüncelerine yer verilmiştir.

Tablo 8: Türkçe öğretmeni adaylarının Osmanlı Türkçesi 1 ve Osmanlı Türkçesi 2 dersinin Türkçe öğretmeni adaylarının istihdam/iş bulmalarına etkisi hakkındaki düşünceleri

\begin{tabular}{lccccccc}
\hline & \multicolumn{3}{c}{ Katılıyorum } & \multicolumn{2}{c}{ Katılmıyorum } & \multicolumn{2}{c}{ Kararsızım } \\
\cline { 2 - 7 } & $\mathbf{\%}$ & $\mathbf{n}$ & $\mathbf{\%}$ & $\mathbf{n}$ & $\mathbf{\%}$ & $\mathbf{n}$ \\
\hline $\begin{array}{l}\text { Osmanlı Türkçesi 1-2 dersi kapsamında öğrendiğim bilgilerin } \\
\text { mezuniyetimden sonra iş bulma (istihdam) konusunda olumlu }\end{array}$ & 37,9 & 105 & 39,3 & 109 & 22,7 & 63 \\
yönde etkili olacağını düşünüyorum. & & & & & & \\
\hline
\end{tabular}

Tablo 8'e göre katılımcılar dersin mezuniyetlerinden sonra istihdamlarına katkıda bulunup bulunmayacağı konusunda farklı görüşe sahiptirler. Osmanlı Türkçesi dersinin istihdamlarına 
olumlu yönde katkıda bulunacağını düşünenlerin de bu görüşü paylaşmayanların da oranının nispeten düşük olduğu söylenebilir. Bu görüşe katılanların oranı \%37,9, katılmayanların oranı ise \%39,3'tür. Aralarındaki fark, bu görüşe katılmayanların lehine \%1,4'tür. Bu maddedeki kararsızların oranı da \%22,7 ile nispeten yüksek sayılabilir.

\section{Osmanlı Türkçesi 1 ve Osmanlı Türkçesi 2 dersinin Türkçe öğretmeni adaylarının kültür ve tarih duyarlılıklarının gelişimine etkisi hakkındaki düşünceleri}

Bu çalışmada Osmanlı Türkçesi 1 ve Osmanlı Türkçesi 2 derslerinin Türkçe öğretmeni adaylarının kültür ve tarih duyarlılıklarının gelişimine etkisi hakkındaki düşüncelerinin ne olduğu anlaşılmaya çalışılmıştır.

Tablo 9'da Osmanlı Türkçesi 1 ve Osmanlı Türkçesi 2 dersinin Türkçe öğretmeni adaylarının kültür ve tarih duyarlılıklarının gelişimine etkisi hakkındaki düşüncelerine yer verilmiştir.

Tablo 9: Osmanlı Türkçesi 1 ve Osmanlı Türkçesi 2 dersinin Türkçe öğretmeni adaylarının kültür ve tarih duyarlılıklarının gelişimine etkisi hakkındaki düşünceleri

\begin{tabular}{|c|c|c|c|c|c|c|}
\hline & \multicolumn{2}{|c|}{ Katılıyorum } & \multicolumn{2}{|c|}{ Katılmiyorum } & \multicolumn{2}{|c|}{ Kararsızım } \\
\hline & $\%$ & $\mathbf{n}$ & $\%$ & $\mathbf{n}$ & $\%$ & $\mathbf{n}$ \\
\hline $\begin{array}{l}\text { Osmanlı Türkçesi 1-2 dersinin Osmanlı Türkçesi etrafında } \\
\text { gelişen kültürü tanımama katkıda bulunduğunu düşünüyorum. }\end{array}$ & 72,4 & 200 & 18,8 & 52 & 9 & 25 \\
\hline $\begin{array}{l}\text { Osmanlı Türkçesi 1-2 dersinin çeşme kitabeleri, mezar taşları } \\
\text { gibi tarihi eserlere sahip çıkma ve onları koruma konusundaki } \\
\text { duyarlılığımın artmasına katkıda bulunduğunu düşünüyorum. }\end{array}$ & 63,9 & 177 & 20,2 & 56 & 15,9 & 44 \\
\hline
\end{tabular}

Tablo 9'a göre katılımcıların büyük çoğunluğu Osmanlı Türkçesi dersinin Osmanlı Türkçesi etrafında gelişine kültürü tanımaları ve çeşme kitabeleri, mezar taşları gibi Osmanlı döneminden kalan tarihî eserlere sahip çıkıp onları koruma konusunda daha duyarlı olmalarını sağladığını düşünmektedir. Bu iki görüşe katılmayanların oranı hemen hemen aynı iken Osmanlı Türkçesi dersinin Osmanlı döneminden kalan tarihî eserlere sahip çıkma ve onları koruma konusundaki duyarlılıklarının arttığını düşünenlerin oranı birinci maddedeki görüşe katılanlara göre yaklaşık \%10 daha düşüktür. Bunun bir sebebi katılımcıların kendi bölgelerinde Osmanlı döneminden herhangi bir tarihî eser kalmamış olması olabilir. Kararsızların oranı bu ikinci maddede birinci maddeye göre yaklaşık \% 7 daha fazladır. Tablodaki tüm maddelere ilişkin kararsızların oranı $\% 9$ ile $\% 15,9$ arasındadır.

\section{Osmanlı Türkçesi 1 ve Osmanlı Türkçesi 2 dersinin Türkçe öğretmeni adaylarının diğer derslere karşı ilgisine etkisi hakkındaki düşünceleri}

Bu çalışmada Osmanlı Türkçesi 1 ve Osmanlı Türkçesi 2 derslerinin Türkçe öğretmeni adaylarının diğer derslere karşı ilgisine etkisi hakkındaki düşüncelerinin ne olduğu anlaşılmaya çalışılmıştır. 
Tablo 10'da Osmanlı Türkçesi 1 ve Osmanlı Türkçesi 2 dersinin Türkçe öğretmeni adaylarının diğer derslere karşı ilgisine etkisi hakkındaki düşüncelerine yer verilmiştir.

Tablo 10: Osmanlı Türkçesi 1 ve Osmanlı Türkçesi 2 dersinin Türkçe öğretmeni adaylarının diğer derslere karşı ilgisine etkisi hakkındaki düşünceleri

\begin{tabular}{|c|c|c|c|c|c|c|}
\hline & \multicolumn{2}{|c|}{ Katılıyorum } & \multicolumn{2}{|c|}{ Katılmıyorum } & \multicolumn{2}{|c|}{ Kararsızım } \\
\hline & $\%$ & $\mathbf{n}$ & $\%$ & $\mathbf{n}$ & $\%$ & $\mathbf{n}$ \\
\hline $\begin{array}{l}\text { Osmanlı Türkçesi 1-2 dersinin edebiyatla ilgili konulara } \\
\text { ilgimin artmasına ve edebî duygularımın gelişimine katkıda } \\
\text { bulunduğunu düşünüyorum. }\end{array}$ & 52,7 & 146 & 28,5 & 79 & 18,8 & 52 \\
\hline $\begin{array}{l}\text { Osmanlı Türkçesi 1-2 dersinin dilbilimine ilgimi artırdığını } \\
\text { düşünüyorum. }\end{array}$ & 46,5 & 129 & 31,4 & 87 & 22 & 61 \\
\hline $\begin{array}{l}\text { Osmanlı Türkçesi 1-2 dersinin tarih bilimine ilgimi artırdığını } \\
\text { düşünüyorum. }\end{array}$ & 48,7 & 135 & 35,4 & 98 & 15,9 & 44 \\
\hline $\begin{array}{l}\text { Osmanlı Türkçesi 1-2 dersinin dil, edebiyat ve tarih gibi alanlar } \\
\text { dışında çalışacaklar için gereksiz olduğunu düşünüyorum. }\end{array}$ & 22,5 & 90 & 50,2 & 139 & 17,3 & 48 \\
\hline
\end{tabular}

Tablo 10’ya göre katılımcıların yarıdan fazlası Osmanlı Türkçesi dersinin edebiyatla ilgili konulara ilgisinin arttığını, edebî duygularının geliştiğini ve Osmanlı Türkçesi dersinin dil, edebiyat ve tarih gibi alanlar dışında çalışacaklar içinde gerekli olduğunu düşünmektedir. Katılımcıların yarıya yakını ise Osmanlı Türkçesi dersinin tarih bilimine ve dilbilimine ilgilerinin artmasına katıkıda bulunduğunu beyan etmektedir. Bu iki bilim arasında ise katılımcıların tarih bilimine ilgisinin arttığını belirtenlerin oranı \%2'ye yakın daha fazladır. Bununla beraber Osmanlı Türkçesi dersinin tarih bilimine ilgilerinin artmasına katkıda bulunmadığını beyan edenlerin oranı dilbilimine ilgilerinin artmadığını belirtenlerin oranından $\% 4$ daha yüksektir. Tüm maddelere ilişkin kararsızların oranı ise $\% 15,9$ ile $\% 22$ arasında değişmektedir.

\section{Osmanlı Türkçesi 1 ve Osmanlı Türkçesi 2 dersi öğretim elemanı ve ders içeriğinin} Türkçe öğretmeni adaylarının derse karşı düşüncelerine etkisi hakkındaki görüşleri

Bu çalışmada Osmanlı Türkçesi 1 ve Osmanlı Türkçesi 2 dersi öğretim elemanı ve ders içeriğinin Türkçe öğretmeni adaylarının derse karşı düşüncelerine etkisi hakkındaki görüşlerinin ne olduğu anlaşılmaya çalışılmıştır.

Tablo 11'de Osmanlı Türkçesi 1 ve Osmanlı Türkçesi 2 dersi öğretim elemanı ve ders içeriğinin Türkçe öğretmeni adaylarının derse karşı düşüncelerine etkisi hakkındaki görüşlerine yer verilmiştir. 
Tablo 11: Osmanlı Türkçesi 1 ve Osmanlı Türkçesi 2 dersi öğretim elemanı ve ders içeriğinin Türkçe öğretmeni adaylarının derse karşı düşüncelerine etkisi hakkındaki görüşleri

\begin{tabular}{|c|c|c|c|c|c|c|}
\hline & \multicolumn{2}{|c|}{ Katilıyorum } & \multicolumn{2}{|c|}{ Katılmiyorum } & \multicolumn{2}{|c|}{ Kararsızım } \\
\hline & $\%$ & $n$ & $\%$ & $\mathbf{n}$ & $\%$ & $\mathbf{n}$ \\
\hline $\begin{array}{l}\text { Osmanlı Türkçesi 1-2 ders öğretim elemanının meslekî ve } \\
\text { pedagojik yeterliliğinin öğrencilerin derse ilişkin düşüncelerini } \\
\text { etkilediğini düşünüyorum. }\end{array}$ & 69,3 & 192 & 13,4 & 38 & 17,3 & 48 \\
\hline $\begin{array}{l}\text { Osmanlı Türkçesi 1-2 dersinde okutulan metin türlerinin, } \\
\text { konularının ve düzeylerinin derse karşı öğrencilerin derse ilişkin } \\
\text { düşüncelerini etkilediğini düşünüyorum. }\end{array}$ & 71,4 & 198 & 14,1 & 39 & 14,4 & 40 \\
\hline
\end{tabular}

Tablo 11'e göre katılımcıların büyük çoğunluğu Osmanlı Türkçesi ders öğretim elemanının meslekî ve pedagojik yeterliliği ile derste okutulan metin türleri, konuları ve düzeylerinin ders hakkındaki düşüncelerini etkilediğini belirtmektedir. Tüm maddelere ilişkin kararsızların oranı ise $\% 14,4$ ile $\% 17,3$ arasında değişmektedir.

\section{Türkçe öğretmeni adaylarının Osmanlı Türkçesi 1 ve Osmanlı Türkçesi 2 dersine ilişkin diğer görüşleri}

Katılımcıların Osmanlı Türkçesi dersine ilişkin diğer düşüncelerinin tespit edilmesi amacıyla formun en sonunda katılımcılara varsa konu ile ilgili diğer düşüncelerini belirtmeleri de istenmiştir. Katılımcıların yalnız 28'i yapılandırılmış maddeler dışında yorum ve düşüncelerini belirtmişlerdir. Ancak bu yorumların çoğunun yapılandırılmış maddeler ile ilgili olduğu görülmüştür. Burada benzer görüşleri belirten katılımcılardan bazılarının görüşlerine imlâlarına dokunulmadan yer verilmiştir. Böylece çalışmanın geçerlik ve güvenirliğinin artırılması amaçlanmıştır. Her bir katılımcıya formu doldurma sıralarına göre bir kod verilmiştir. Her katılımcı buna göre A1, A2, A3... şeklinde kodlanmıştır.

Çalışmanın nitel bölümünden elde edilen bulgular şu şekilde özetlenebilir:

Katılımcıların bazıları Osmanlı Türkçesinin öğretiminde geleneksel yöntemlerin kullanıldığını belirterek bunların gözden geçirilmesi gerektiğini belirtmişlerdir:

A25: "Osmanlı Türkçesi doğru kişiler tarafindan ve doğru sistemle verilirse özellikle Tarih, Edebiyat ve Türkçe okuyanlar dersin zarurîyetini kesinlikle anlar. Fakat okuldaki öğretim sistemi nedeniyle Osmanlı Türkçesi dersine öğrenciler "öcü” gibi bakıyor. Dil mevzunda eğitimin daha hassas olması gerektiğini düşünüyorum."

A206: "Genel olarak ders yeni gelenlerin yabancısı olduğu bir ders olduğu için ilk başlarda sıkıcı olduğunu düşünüyorum. İlerleyen safhalarda bilgi artışıyla ilgi artışının birlikte arttığını gözlemledim. Konusu bakımından geleneksel yöntemlerle işlenen bir ders olması olumsuz görüşlerimin temelini oluşturuyor.”

A263: "Osmanlıca derslerinin daha verimli geçmesi için farklı teknikler konuşma ve okuma üzerinde daha fazla durulmalı.” 
Katılımcıların bazıları ders öğretim sürecinde öğrenci seviyesinin göz önüne alınmadığını belirtmektedirler:

A203: “Osmanlıca derslerinin öğrencilerin seviyesine göre olması gerektiğini düşünüyorum. Örn. Alfabeyi bilmeyenlerin üzerinde daha fazla durulması gerekiyor."

A266: "Osmanlıca eğitimi türkçe öğretmenliği öğrencileri için gereksiz bir ders. İmamhatip lise mezunu öğrencileri daha önceden gördüklerinden onlara yönelik eğitim veriliyor ve bilmeyen öğrenciler hiç önemsenmiyor. Bu yüzden hem yeteri kadar öğrenemedim hem ilgimi çekmedi.”

Katılımcıların bazıları Osmanlı Türkçesinde dilbilgisinden ziyade kelime hazinelerinin gelişmesine yönelik bir yaklaşım sergilenmesi gerektiğini şu cümlelerle belirtmişlerdir:

A4: “Türkçe Öğretmenliği’ne yönelik verilen Osmanlı Türkçesi 1-2 derslerinin gramer düzeyinin azaltılıp kelime hazinesini geliştirmeye yönelik kelime bilgisi düzeyinin artırılması gerektiği kanaatindeyim.”

Daha önce de belirtildiği üzere katılımcıların \% 55,9 (n=155)'u ders süresinin yeterli olduğunu düşünürken \%26,4 (n=83)'ü ise bu görüşe katılmamaktadır. Osmanlı Türkçesi ders süresinin artırılması gerektiğini düşünen katılımcıları konu ile ilgili düşüncelerini şu cümlelerle belirtmişlerdir:

A13: “Osmanlı Türkçesi dersinin, ders saatinin arttırılması gerektiğini düşünüyorum. Bizler TÜRKÇECIYIZI! Türkçenin her dönemini tanımalı, bilmeli, öğrenmeliyiz. Osmanlıcanın bazı öğrencilere zor ya da ağır gelmesi bu gerçeği değiştiremez! O zaman Türk dili okumasınlar! Bu bizim kültürümüz, atalarımızın mirası.. Ders sayısı arttırılmalı her seneye Osmanlı Türkçesi dersi koyulmalıdır.Türkçe öğretmeni olacağız ve dersin adı osmanlı TÜRKÇESİ.” A48: "Bu dersin daha fazla dönemde görülmesi gerektiğini düşünüyorum. Osmanlı Türkçesi 3-4 şeklinde. 2.sınıftan itibaren verilmesi öğrenciler için daha uygun. Bölüme ilişkin bilincimizin oturması bu evrelerde başlıyor. Kelime hazinesi bakımından dersi yetersiz buldum okuduğum dönemde. Şu an bilgim kelimelerin tamamına yakınını başka derslerden öğrendim. Yazma becerisinin okumadan oldukça geri kaldığını düşünüyorum.Bu derse merakım 3.sınıfta başladı. Bu sene son senem ve dersle alakalı kurslara katılıp kendimi geliştirmeyi düşünüyorum.”

Bu cümlelerden de anlaşılabileceği gibi Osmanlı Türkçesi ders saatinin artılması gerektiğini düşünen katılımcılar düşüncelerini Türkçenin geçmiş tarihî dönemlerini bilmeleri gerektiği, kültürümüzün ve atalarımızın mirası olması, meslekleriyle olan sıkı ilişkisi, bölüme ilişkin bilinçlerinin daha sonraki yıllarda oturmaya başlaması, yazma becerisinin daha yeterli hâle getirilmesi gibi temellere dayandırmaktadırlar.

Daha önce de belirtildiği üzere katılımcıların \% 60,7 (n=168)'i Osmanlı Türkçesi dersinin Türkçe eğitiminin amaçlarına uygun olduğunu, dolayısıyla Türkçe öğretmeni adayları için gerekli olduğunu düşünürken \% 27,1 (n=75)'i ise bu görüşe katılmamaktadır. Osmanlı Türkçesinin gerekliliğine inanan Türkçe öğretmen adayları görüşlerini şu cümlelerle belirtmişlerdir: 
A68: "Osmanlıca dersi bence her üniversite öğrencisinin kesinlikle alması gereken bir ders özellikle eğitim fakülteleri Peyami sefanın çok sevdiğim bir sözü var bizler kendi kütüphanesine giripte tek bir kitap okumadan çıkan milletiz. Ayrıca bir eserin orjinalinden okunması gerektiğini düşünüyorum. Çevirilen eserlerin tam olarak içeriklerini yansıttıklarına inanmiyorum. Bazen taraf tutuyorlar."

A82: "Osmanlı Türkçesi diger öğretmenlik bölümlerine [de] zorunlu olsa faydalı olur onların ilmi açısından."

A112: “Osmanlı Türkçesi öğrenmek genel olarak öğrenciler tarafından gereksiz gibi görülse de aslında İlber Ortaylı'nın da dediği gibi tüm Türkiye'nin öğrenmesi bilmesi gerekir. Benim fikrim de bununla aynı şekildedir."

A127: "Osmanlı Türkçesi dersinin her bölümde okutulması gerektiğini düşünüyorum. Çünkü geçmişimizi birinci kaynaktan okumamız hepimiz için daha faydalıdır."

A217: "Metinleri çözerken keyif alıyorum ve beni dışarıdaki diğer insanlardan farklı kılacağını düşünüyorum. Bir aday olarak dil bilgisi derslerinin artması gerektiğini düşünüyorum.”

Bu cümlelerden de anlaşıldığı gibi Türkçe öğretmeni adayları Osmanlı Türkçesi dersinin gerekliliği konusundaki görüşlerini eski eserlere orijinalinden ulaşmanın gerekliliği, faydalı olacağı, birincil kaynaklara ulaşmayı sağlayacağı, Osmanlı Türkçesi bilmenin kendilerini diğer insanlardan farklı kılacağı gibi temellere dayandırmaktadırlar.

Daha önce de belirtildiği üzere katılımcıların \%43,3 (n=120)'ü Osmanlı Türkçesi dersinin seçmeli olması gerektiğini, \%45,1 (n=125)'i ise dersin zorunlu olması gerektiğini düşünmektedirler. Osmanlı Türkçesi dersinin seçmeli olması gerektiğini düşünen katılımcılar bu düşüncelerini öğrencilerin farklı alanlara yönelebilmesine imkân tanınmasını gerekçe olarak göstermektedirler:

A20: "Bu ders seçmeli olmalı. Tıpkı diğer dersler gibi. Öğrenci başka başka alanlara da yönelebilmeli."

Osmanlı Türkçesi dersinin Türkçe eğitimi öğretim programından tamamen kaldırılması gerektiğini düşünenler ise düşüncelerini şu cümlelerle belirtmişlerdir:

A78: "Osmanlı Türkçesi ayrı bir alan oldugunu dusunuyorum yazı ile ilgilenenler almalı bu dersi. Türkçe, Edebiyat, Dil oğretmen adayiyiz biz Osmanlica ogretmeyecegiz Türkçe ögretecegiz. Teşekkürler."

A126: "Osmanlıca Türkçe si gereksiz bir ders ilerde meslek hayatımda asla ihtiyaç duymayacagim."

A147: "Türkçe eğitimi için tamamen gereksiz, hiçbir faydası olmadığını düşündüğüm bir ders. Öğretiminde kullanılan yöntem ve teknikler de çok sıradan. Mesleki gelişim açısından hiçbir katkı sağlamadı."

A170: "Bu dersin bölüme hiçbir katkı sağladığını düşünmüyorum,üstelik öğretmenlerin dahi bu dersin üstüne düşmediğini düşünüyorum.”

A178: "Osmanlıca dersinin türkçe öğretmenliği programında olması tamamen yanlış buluyorum. Dersin öğrenciye veya mesleki gelişime katkı sunmadığını düşünüyorum.” 
A239: "Lütfen bu dersi kaldırın hem geçmek çok zor hem de edebiyat okuyan öğrenciler için bu ders zorunlu olsun. Türkçe eğitimi bölümünde bu dersin diğer hiçbir alan dersimize faydalı olduğunu düşünmüyorum. Bu ders kalksın eski edebiyat dersimiz bizim için yeterlidir." A256: "Osmanlıca evet okutulması öğretilmesi gereken bir ders ama bu bazı bölümler için geçerlidir. Türkçe öğretmenliği alanında olmaması gerekiyor çünkü bizim alanımız Türkçe buna yönelik derslerin olması gerekli diye düşünüyorum."

Bu cümlelerden de anlaşılabileceği gibi Osmanlı Türkçesi dersinin gereksiz olduğuna inanan katılımcılar düşüncelerini Osmanlı Türkçesi öğretmeyecekleri, dolayısıyla meslek hayatlarında gerek duymayacakları, dersin meslekî gelişim açısından kendilerine katkı sağlamadığı, ders öğretim elemanlarının da dersin önemsiz olduğunu hissettirdikleri, dersin zor olduğu, dersin diğer alan dersleri ile ilişkisiz olduğu, dersin alan dışı bir ders olması gibi temellere dayandirmaktadırlar.

Daha önce de belirtildiği gibi Türkçe öğretmen adaylarının \%69,3 (n=192)'ü ders öğretim elemanının meslekî ve pedagojik yeterliliğinin ders hakkındaki düşüncelerini etkilediğini, \%13,4 (38)'ü ise bu düşünceye katılmadıklarını belirtmişlerdir. Bu bağlamda katılımcıların bazıları ders öğretim elemanının önemine dikkat çekerek ders öğretim elemanının meslekî ve pedagojik açıdan daha iyi hâle gelmesi gerektiğini düşünmektedirler:

A124: "Bu dersi veren öğretmen de önemli. Öğretmen bilgili, yeni öğretim tekniklerine sahib ise öğrenci de bu dersi sıkılmadan dinler ve yapar. Daha fazla ayrıntıya girmeden ve sıkmadan da anlatmak önemli. Çünkü çoğu öğrenci Arapça ve Farsça kelimeleri bilmiyor. Bu yüzden yazmak ve konuşmak zor olabilir ilk başlarda."

A200: "Öğretim elemanının tutum ve dersi anlatma şekli de derse olan ilgiyi arttırabilir." A235: "Osmanlı Türkçesini aldigim hocanın beni dersten soğuttuğunu düşünüyorum. Her iki dönem dersten de kaldım bence bu dersi öğrencilere sevdirecek başka bir hocaya verilmesi taraftarıyım."

Bunlar arasında ders öğretim elemanının tutum ve ders anlatma şeklinin öğrencilerin akademik başarılarını etkilediğini belirten cümleleri özellikle belirtmek gerekir.

\section{Tartışma}

Lise ve üniversite düzeyindeki öğrencilerin Osmanlı Türkçesi dersine karşı ilgi, düşünce veya tutumlarının araştırıldığı araştırmalarda ${ }^{38}$ katılımcıların Osmanlı Türkçesi veya dersine ilişkin genel yaklaşımlarının olumlu olduğu ortaya konmuştur. Bu çalışmada da katılımcıların \%62,3 (n=162)'nün Osmanlı Türkçesi dersine ilişkin genel düşüncelerinin olumlu olduğu tespit edilmiştir. Bu yönüyle çalışmanın önceki çalışma sonuçları ile uyumlu olduğu söylenebilir.

38 Necmettin Özmen ve Bilal Yıldırım, "Üniversite Öğrencilerinin Osmanlı Türkçesine İlişsin Tutumları" Dil ve Edebiyat Araştırmalarl, 16 (2017), 49-66; Ramazan Kaya, "Tarih Öğretmen Adaylarının Lisans Eğitiminde Osmanlıca Öğretiminin İşlevselliği İle İlgili Görüşleri” Atatürk Üniversitesi Sosyal Bilimler Enstitüsü Dergisi, 17, 2 (2013), 187-206; Oğuzhan Sevim ve Hatice Bayındır, "Lise Ve Üniversite Öğrencilerinin Osmanlı Türkçesi Dersine Yönelik Görüşlerinin İncelenmesi” Ekev Akademi Dergisi, 20, 67 (2016), 291-302. 
Tarih öğretmeni adayları üzerinde yapılan bir araştırmada ${ }^{39}$ ise katılımcıların büyük çoğunluğunun Osmanlı Türkçesi bilmenin gerekliliğini meslekî ve toplumsal saygı kazanmaya bağlamış oldukları tespit edilmiştir. Katılımcılar ayrıca Osmanlı Türkçesi bilmenin tarih öğretmenine birincil kaynaklara ulaşabilme ve öğrencilerine bu kaynaklardaki kavramları açıklayabilme imkânı tanıdığından dolayı da Osmanlı Türkçesi öğrenmenin gerekliliğine inanmaktadırlar. Katılımcılara göre Osmanlı Türkçesi meslekî hayatları için de gerekli bir derstir. Elinizdeki araştırmada da katılımcılardan çoğunluğu Osmanlı Türkçesi dersinde edindikleri bilgi ve becerilerin meslekî hayatlarına katkıda bulunacağını ve Osmanlı Türkçesi dersinin herkes için gerekli bir ders olduğunu düşünmektedir. Buna göre Türkçe ve tarih öğretmen adaylarının Osmanlı Türkçesi öğrenmelerinin meslekî hayatları için gerekli olduğunu düşündükleri anlaşılmaktadır.

Başka bir araştırmada ${ }^{40}$ ise lise ve üniversite düzeyindeki öğrencilerin Osmanlı Türkçesi öğretiminin millî tarih, millî edebiyat ve geçmişle kurulan manevî bağlar gibi nedenlerle gerekli olduğunu düşündükleri ortaya konmuştur. Bu katılımcılar Osmanlı Türkçesi dersinin dil, edebiyat ve tarih gibi alanlar dışında çalışacaklar için gereksiz bir ders olduğunu da beyan etmektedirler. Söz konusu araştırmada bu yüzden dersin ilgilerini çekmediğini belirten lise veya üniversite öğrencilerinin görüşlerine yer verilmiştir. Benzer şekilde Sosyal Bilimler Lisesi öğrencileri üzerinde yapılan bir çalışmada (Çalışkan, 2013) katılımcıların büyük çoğunluğunun Osmanlı Türkçesi dersinin meslek hayatlarında kendilerine herhangi bir katkıda bulunmayacağını düşündüklerini beyan etmeleri ilgi çekicidir. Hâlbuki elinizdeki çalışmada Osmanlı Türkçesinin dil, edebiyat ve tarih gibi alanlar dışında çalışacaklar için de gerekli olduğunu düşünenlerin oranı \% 50,2 ’ dir. Bu konuda elinizdeki çalışma ile önceki çalışmaların sonuçları arasında tam bir uyum olduğu söylenemez.

Lise düzeyindeki öğrencilerinin Osmanlı Türkçesi dersinin kolaylığı konusunda yarıdan fazlasının dersi kolay bulmasına rağmen üniversite öğrencilerinin yaklaşı \% 80 ’inin dersi zor buldukları belirtilmektedir. ${ }^{41}$ Elinizdeki çalışmada ise katılımcıların yarıdan fazlası Osmanlı Türkçesi dersini keyifli bulmakla birlikte dersin zor olduğunu düşünmektedir. Bu yönüyle her iki çalışmanın sonuçlarına göre katılımcıların çoğunluğunun Osmanlı Türkçesi dersini kolay bulmadıkları anlaşılmaktadır.

Sosyal Bilimler Lisesi öğrencileri not ortalamalarını düşürdüğü ve mesleki hayatlarına katkısı olmayacağına inandıkları için Osmanlı Türkçesi dersinin seçmeli olması gerektiği düşünmektedir (Çalışkan, 2013, s. 333). Tarih öğretmen adaylarının çoğunun sadece matbu metinlerin işlendiği Osmanlı Türkçesi derslerinin zorunlu, yazma metinlerin işlendiği Osmanlı

39 Ramazan Kaya, "Tarih Öğretmen Adaylarının Lisans Eğitiminde Osmanlıca Öğretiminin İşlevselliği İle İlgili Görüşleri” Atatürk Üniversitesi Sosyal Bilimler Enstitüsü Dergisi, 17, 2 (2013), 197-199.

40 Oğuzhan Sevim ve Hatice Bayındır, "Lise Ve Üniversite Öğrencilerinin Osmanlı Türkçesi Dersine Yönelik Görüşlerinin İncelenmesi” Ekev Akademi Dergisi, 20, 67 (2016), 291-302.

41 Oğuzhan Sevim ve Hatice Bayındır, "Lise Ve Üniversite Öğrencilerinin Osmanlı Türkçesi Dersine Yönelik Görüşlerinin İncelenmesi” Ekev Akademi Dergisi, 20, 67 (2016), 299. 
Türkçesi derslerinin seçmeli olması gerektiğini düşündükleri yapılan başka bir araştırmayla (Kaya, 2013, s. 195) ortaya konmuştur. Elinizdeki çalışmada ise Osmanlı Türkçesi dersinin seçmeli olması gerektiğini düşünenlerin oranı \%43,3 ile zorunlu olarak kalması gerektiği düşünenlerin oranı \%45,1 ile hemen hemen aynıdır. Bu durum Türkçe öğretmeni adaylarının düzeyleri ve alanları itibariyle daha rasyonel (ölçülü, gerçekçi) değerlendirme yapabildikleri ile açıklanabilir.

Elinizdeki çalışmada katılımcıların \%37-38'i kendilerini Osmanlı Türkçesi konusunda yeterli görürken Sosyal Bilimler Lisesi öğrencileri üzerinde yapılan bir çalışmada (Çalışkan, 2013, s. 334) öğrencilerin çoğunluğunun kendileri orta ve iyi seviyede gördükleri ortaya konmuştur. Tarih öğretmen adayları üzerinde yapılan araştırmaya (Kaya, 2013, 191-192) göre ise Tarih öğretmeni adaylarının tamamına yakını matbu metinleri okuyup anlama konusunda kendilerini yeterli görmektedir. Ancak yazma eserlere ilişkin okuyup anlama özyeterlik oranları ise \%33 ile \%25'ler civarındadır. Bu durumda katılımcıların Osmanlı Türkçesi konusunda kendilerini yeterli görüp görmemelerinin akademik seviyelerine göre kendilerine verilen eğitim düzeyi ile ilgili olduğu ileri sürülebilir. Türkçe öğretmen adaylarından oransal olarak daha azının kendilerini Osmanlı Türkçesi konusunda yeterli görmekte olduğu anlaşılmaktadır.

Sosyal Bilimler Lisesi öğrencilerinin çoğunluğu dersi aldıktan sonra Osmanlı Türkçesine karşı daha bilinçli hâle geldiklerini ifade etmişlerdir. Öğrencilerin dersten önce Osmanlı Türkçesine karşı olumlu düşüncelere sahip olanların dersi aldıktan sonra bu düşüncelerinin pekiştiği de belirtilmektedir (Çalışkan, 2013, s. 337-338). Elinizdeki çalışmada da katılımcıların yarıdan fazlası Osmanlı Türkçesine karşı genel olarak olumlu düşüncelere sahip olduklarını ifade etmişlerdir. Osmanlı Türkçesi dersi sayesinde Türk diline ve genel olarak dile karşı bilinçlenme düzeylerinin arttığını belirtenlerin oranı da oldukça yüksektir. Sonuç olarak her iki çalışmada da bu konuda benzer sonuçların ortaya çıktığı anlaşılmaktadır.

Lisans düzeyindeki Bilgi ve Belge Yönetimi bölümlerinin programlarında yer alan Osmanlı Türkçesi derslerinin değerlendirildiği bir çalışmada ${ }^{42}$ bu bölüm öğrencilerinin istihdamlarında Osmanlı Türkçesini bilmenin çok gerekli olduğu ileri sürülmektedir. Çünkü konu ile ilgili iş ilanlarında çoğu zaman Osmanlı Türkçesi bilme şartının konduğu tespit edilmiştir. Elinizdeki çalışmada ise Osmanlı Türkçesi bilmenin istihdamlarında avantaj sağlayacağını düşünenler ile bu görüşe katılmayanların oranı yaklaşık \%37-40 civarındadır. Konu ile ilgili olarak her iki görüşte olanların oranının görece düşük olduğu söylenebilir. Bu durum, öğretmen olmak için Osmanlı Türkçesi bilmek gibi bir şartın olmamasından kaynaklanmalıdır. Bununla beraber söz konusu durum, Türkçe öğretmen adaylarının öğretmenlik mesleği dışında (herhangi bir kamu/özel kurumda kütüphane vb. alanlarda uzman olma gibi) bir düşünce veya bilgiye sahip olmadıkları ile de açıklanabilir.

42 Malik Yılmaz ve B. Aydemir Şenay, "Türkiye'deki Bilgi ve Belge Yönetimi Bölümlerinin Lisans Ders Programlarında Yer Alan Osmanlı Türkçesi Derslerinin Değerlendirilmesi ve İstihdamdaki Önemi” Atatürk Üniversitesi Sosyal Bilimler Enstitüsü Dergisi, 18, 3 (2014), 1-10. 


\section{Sonuç}

Bu çalışmada Türkçe öğretmen adaylarının lisans programında birinci ve ikinci yarıyılda ikişer saat olmak üzere toplam iki dönemde Osmanlı Türkçesi 1 ve Osmanlı Türkçesi 2 adlarıyla okutulan derse ilişkin görüşlerini tespit etmek amaçlanmıştır. Bu amaçla 15 değişik üniversiteden 277 Türkçe öğretmen adayına üçlü likert tipinde 9 farklı kategoride 35 farklı maddeden ve bir açık uçlu kısımdan oluşan çevirimiçi ortamda bir ölçme aracı uygulanmıştır.

Türkçe öğretmeni adaylarının Osmanlı Türkçesi 1 ve Osmanlı Türkçesi 2 dersinin Türkçe Eğitimi Ana Bilim Dalı lisans programındaki varlığı, yeri ve gereği hakkındaki düşüncelerine bakıldığında Türkçe öğretmeni adayları genel olarak Osmanlı Türkçesi dersinin Türkçe eğitiminin amaçlarına uygun, mevcut ders süresinin yeterli ve ders kapsamındaki bilgilerin kendileri için yeterli, dersin mevcut hâldeki gibi birinci sınıfta verilmesinin uygun olduğunu ve dersin beklentilerini karşıladıklarını ve dersin zorunlu değil, seçmeli olması gerektiğini düşündükleri görülmektedir.

Osmanlı Türkçesi 1 ve Osmanlı Türkçesi 2 dersinin Türkçe öğretmeni adaylarının bilişsel/ akademik gelişimlerine etkisi hakkındaki düşüncelerine bakıldığında Türkçe öğretmeni adayları genel olarak Osmanlı Türkçesi dersi sayesinde Arapça ve Farsça ile ilgili bilgilerinin ve kelime hazinelerinin arttığını, Türkçe ve dil bilinçlerinin geliştiğini, akademik başarılarının arttığını, okuduğunu anlama becerilerinin geliştiğini ve farklı alanlara ilgilerinin uyandığını belirtmişlerdir. Bununla beraber katılımcıların çoğunluğu Osmanlı Türkçesi dersinin dinleme ve konuşma becerilerine fazla etkisi olmadığını düşünmektedir.

Osmanlı Türkçesi 1 ve Osmanlı Türkçesi 2 dersinin Türkçe öğretmeni adaylarının duyuşsal gelişimlerine etkisi hakkındaki düşüncelerine bakıldığında Türkçe öğretmeni adaylarının genel olarak Osmanlı Türkçesine karşı olumlu bir görüşe sahip oldukları, dersteki etkinleri anlamlı buldukları ve dersin millî duygularının gelişmesine katkıda bulunduğunu düşündükleri görülmektedir. Katılımcıların çoğunluğu Osmanlı Türkçesi ile yazılmış metinleri okurken duygusal coşkunluk yaşayıp heyecanlandıklarını belirtmişlerdir.

Osmanlı Türkçesi 1 ve Osmanlı Türkçesi 2 dersinin Türkçe öğretmeni adaylarının özgüvenleri/özgelişimlerine etkisi hakkındaki düşüncelerine bakıldığında Türkçe öğretmeni adayları genel olarak kendilerini Osmanlı Türkçesi konusunda yeterli görmemektedirler. Dersi keyifli bulmalarına rağmen dersin öğrenilmesinin kolay olmadığını belirtmişlerdir.

Osmanlı Türkçesi 1 ve Osmanlı Türkçesi 2 dersinin Türkçe öğretmeni adaylarının meslekî gelişimlerine etkisi hakkındaki düşüncelerine bakıldığında Türkçe öğretmeni adaylarının genel olarak Osmanlı Türkçesi dersinin bilgi ve beceri anlamında meslekî hayatlarına, okuma-yazma alışkanlıklarının pekişmesine, meslekî özgüvenlerin artmasına ve mesleklerine karşı daha meraklı hâle gelmelerine katkıda bulunduğunu düşündükleri görülmektedir.

Osmanlı Türkçesi 1 ve Osmanlı Türkçesi 2 dersinin Türkçe öğretmeni adaylarının istihdam/ iş bulmalarına etkisi hakkındaki düşüncelerine bakıldığında öğretmen adaylarının genel olarak Osmanlı Türkçesi dersinde edindiği bilgi ve becerilerin iş bulmalarına katkıda bulunup 
bulunmayacağı konusundaki görüşlerinde katılıyorum, katılmıyorum, kararsızım seçeneklerinden herhangi birinde dikkate değer oranda yoğunlaşmadıkları görülmektedir.

Osmanlı Türkçesi 1 ve Osmanlı Türkçesi 2 dersinin Türkçe öğretmeni adaylarının kültür ve tarih duyarlılıklarının gelişimine etkisi hakkındaki düşüncelerine bakıldığında Türkçe öğretmeni adaylarının genel olarak Osmanlı Türkçesi dersi sayesinde Osmanlı Türkçesi etrafında gelişen kültürü daha iyi tanıdıkları ve bu dilin konuşulduğu dönemden günümüze kalmış tarihî eserleri koruyup sahiplenme konusunda daha duyarlı hâle geldiklerini düşündükleri söylenebilir.

Osmanlı Türkçesi 1 ve Osmanlı Türkçesi 2 dersinin Türkçe öğretmeni adaylarının diğer derslere karşı ilgisine etkisi hakkındaki düşüncelerine bakıldığında Türkçe öğretmeni adaylarının genel olarak Osmanlı Türkçesi dersinin edebiyatla ilgili konulara ve edebî duygularının gelişmesine katkıda bulunduğunu, bu dersin dil, edebiyat ve tarih alanı dışında çalışanlar için de gerekli olduğunu, tarih bilimine ve dilbilimine ilgilerinin artmasına katkıda bulunduğunu beyan ettikleri görülmektedir.

Osmanlı Türkçesi 1 ve Osmanlı Türkçesi 2 dersi öğretim elemanı ve ders içeriğinin Türkçe öğretmeni adaylarının derse karşı düşüncelerine etkisi hakkındaki görüşlerine bakıldığında Türkçe öğretmeni adaylarının genel olarak Osmanlı Türkçesi ders öğretim elemanının nitelikleri ile ders kapsamında görülen metinlerin özelliklerinin derse karşı düşüncelerini etkilediğini söylemek mümkündür.

\section{1. Öneriler}

Öncelikle Osmanlı Türkçesi dersi öğretim elemanları Türkçe öğretmeni adaylarına öncelikle Osmanlı Türkçesinin ne olduğu, Türkçe öğretimi açısından gerekliliği, dil bakımından Türkiye Türkçesinin öğretimine katkısı gibi konular üzerinde durabilir. Bu bilgiler inandırıcı, ikna edici ve örneklendirici bir anlatımla verilebilir. Yapılan araştırmada Türkçe öğretmeni adaylarının büyük çoğunluğunun Osmanlı Türkçesi ve bu derse karşı düşünce ve ilgilerinin birçok açıdan oldukça olumlu olduğu, dersin Türkçe eğitiminin amacına uygun bir ders olduğunu düşündükleri dikkati çekmektedir. Buna rağmen Türkçe öğretmeni adayları dersin seçmeli olması gerektiğini beyan etmişlerdir. Bu düşüncede Türkçe öğretmeni adaylarının akademik başarılarını önceleyerek öğrenci mantıkıyla hareket ettiklerinin etkili olduğu ileri sürülebilir. Buna bağlı olarak bu durumun kendi içinde tutarlı olmadığı görülmektedir.

Türkçe öğretmeni adaylarında bulunduğu varsayılan dersin zor olduğuna dair önyargıların ders öğretim elemanları tarafından giderilmeye çalışılması önerilebilir. Bununla beraber ders öğretim elemanının dersi yürütürken dersteki öğrencilerin hazır bulunuşluk seviyelerinin farklı olduğunu göz önüne alması faydalı olabilir. Yapılan araştırmada Türkçe öğretmen adaylarının Osmanlı Türkçesi dersini öğrenilmesi keyifli ancak zor olarak tanımladıkları görülmektedir. Burada Türkçe öğretmen adaylarının Osmanlı Türkçesi dersine karşı olumlu bir yaklaşımları olduğu ancak öğrenmekte zorlandıkları anlaşılmaktadır.

Türkçe öğretmen adayları Osmanlı Türkçesi sayesinde dil, edebiyat, tarih, dilbilim gibi 
alanlara ilgilerinin arttığını, meslekî hayatlarına katkıda bulunacağına inandıkları, millî duygu ve düşüncelerinin gelişmesine katkıda bulunduğunu vb. beyan etmişlerdir. Ancak bu kadar önemli olmasına ve çeşitli açılardan oldukça olumlu katkıları olması rağmen Türkçe öğretmen adayları kendilerini Osmanlı Türkçesi dersi konusunda yeterli görmemektedirler. Bunun yanında Türkçe öğretmeni adayları dersin süresinin ve içeriğinin kendileri için yeterli olduğunu da belirtmektedirler. Bu durumda her iki düşüncenin kendi içinde tutarlı olmadığ 1 görülmektedir. Türkçe öğretmeni adaylarının bu hususta da yine öğrenci mantıkıyla hareket ettikleri düşünülebilir. Ancak Türkçe öğretmeni adaylarının Osmanlı Türkçesi dersi konusunda yetersiz oldukları önümüzde bir sorun olarak durmaktadır. Bunun çözümünde ilk akla gelen, ders öğretim elemanının dersi daha verimli hâle getirmek için daha fazla çaba göstermesinin gerekliliğidir. Zira Türkçe eğitimi ile ilgili yapılan bir araştırmada ${ }^{43}$ öğrencilerin çoğunluğunun genel derslerle ilgili olarak ders öğretim elemanlarının isteksiz, materyal kullanımlarının yetersiz olduğunu vb. düşündükleri ortaya konmuştur. Benzer şekilde bu çalışmamızda da katılımcıların büyük çoğunluğu ders öğretim elemanının meslekî ve pedagojik özelliklerinin öğrencilerin derse karşı düşünce ve tutumlarının şekillenmesinde çok etkili olduğunu belirtmişlerdir. Bu durumda sorunun çözümü için ders öğretim elemanının meslekî ve pedagojik yeterlilik bakımından mümkün olduğunca tecrübeli olması, dersin işlenişinde materyal kullanımı ve Türkçe dersi öğretim yöntemlerini aktif olarak kullanması önerilebilir. İkinci olarak her ne kadar katılımcılar dersin süresinin ve içeriğinin kendileri için yeterli olduğu görüşünde iseler de sonuç itibariyle mevcut Osmanlı Türkçesi dersi eğitiminin Türkçe öğretmen adaylarının ders ile ilgili yeterlilik kazanmasına kâfi gelmediği anlaşılmaktadır. Bunun için Türkçe eğitimi Ana Bilim Dalı'nda derslerin süresinin haftada iki saat yerine üç saat olarak düzenlenmesi, dersin 2., 3, ve/veya 4. sınıflarda seçmeli veya zorunlu olarak devam ettirilmesi önerilebilir. Nitekim sadece birinci sınıfta haftada ikişer saat olarak alınan derste edinilen bilgi ve becerilerin çoğunun öğrencilerin mezuniyetlerine kadar köreleceği öngörülmektedir. Osmanlı Türkçesi ilk veya ortaöğretimde seçmeli yahut zorunlu olarak verildiği/verilebileceği de göz önüne alındığında bu sorunu çözmenin daha da önemli olduğu anlaşılacaktır.

Ders kapsamındaki metinlerin konu, düzey ve tür bakımından amaçlı bir şekilde seçilmesine özen gösterilmesi önemlidir. Bu bağlamda ders kapsamında millî ve evrensel değerleri önceleyen, kelime hazinesi bakımından zengin, edebî zevkin gelişimine katkıda bulunan vb. niteliklere sahip metinlerin okutulması önerilebilir. Yapılan çalışmada Türkçe öğretmen adayları Osmanlı Türkçesi dersi sayesinde kelime hazinelerinin arttığını, dersin yazma ve okuma becerilerinin gelişmesine katkıda bulunduğunu belirtmektedirler. Buna karşın Osmanlı Türkçesi dersinin katılımcıların dinleme ve konuşma becerilerine kayda değer bir katkısı olmadığını beyan ettikleri görülmektedir. Hâlbuki kelime hazinesinin artmasıyla dinleme ve konuşma becerilerinin de gelişmesi beklenen bir gelişmedir. Burada ders kapsamındaki metinlerin öğrencilerin kelime

43 Bülent Özkan ve, N. Kemal Şahbaz “Türkçe Öğretmeni Adaylarının Alan Derslerinin İşlevselliğine Yönelik Görüşleri” Sakarya University Journal of Education, 1, 1 (2011), 32-43. 
hazinelerinin gelişmesine yeteri kadar katkıda bulunmadığı ileri sürülebilir. Nitekim bu çalışmada katılımcılar ders kapsamındaki metinlerin konu, düzey ve tür olarak oldukça önemli etkilere sahip olduğunu belirtmişlerdir.

Türkçe öğretmeni adaylarının motivasyonunu artırmak ve onlara istihdamları açısından farklı bir bakış açısı kazandırmak için ders öğretim elemanının değişik kurumların Osmanlı Türkçesi bilme şartı ile uzman eleman aradıklarını paylaşması önerilebilir. Bunun yanında yayıncılık, editörlük, araştırmacılık gibi alanlarda da bu derste edindikleri bilgi ve becerileri kullanabilecekleri Türkçe öğretmeni adaylarına örneklerle anlatılabilir. Yapılan çalışmada Türkçe öğretmen adaylarının mezuniyet sonrası istihdamlarında Osmanlı Türkçesi dersinin etkisinin ne olacağı konusunda belirsiz düşüncelere sahip oldukları görülmektedir. Bunun sebebi, öğretmen atama sürecinde Osmanlı Türkçesi dersi ile ilgili herhangi bir şart veya bilgi olmaması olmalıdır. Bu yüzden Türkçe öğretmen adayları Osmanlı Türkçesinin -diğer derslerden farklı olarak- istihdamları konusunda herhangi bir katkıda bulunup bulunmayacağı konusunda kesin düşüncelere sahip olmamaları normaldir. Burada Türkçe öğretmen adaylarının öğretmenlik mesleğinden başka bir mesleğe yönelme gibi bir düşüncede olmadıkları da öngörülebilir.

Hakem Değerlendirmesi: Dış bağımsız.

Çıkar Çatışması: Yazar çıkar çatışması bildirmemiştir.

Finansal Destek: Yazar bu çalışma için finansal destek almadığını beyan etmiştir.

Peer-review: Externally peer-reviewed.

Conflict of Interest: The author has no conflict of interest to declare.

Grant Support: The author declared that this study has received no financial support.

\section{Kaynaklar/References}

Akpınar, Şerife. "Osmanlı Türkçesi Öğretimi Üzerine.” Journal of International Social Research, 9, 44 (2016): 7-12.

Baran, Burhan. "Osmanlı Türkçesi Öğretiminde Arapça, Farş̧a ve Eski Anadolu Türkçesinin Yeri.” Uluslararası Türkçe Edebiyat Kültür Eğitim Dergisi (TEKE), 7, 4 (2018): 2131-2142.

Başkan, Ahmet ve Altunkaya, Hatice. "Türkçe Öğretmeni Adaylarının Osmanlı Türkçesi Dersine Yönelik Öğrenen Güçlenmesi Düzeyleri.” Afyon Kocatepe Üniversitesi Sosyal Bilimler Dergisi, 21, 3 (2019): 808-815.

Büyüköztürk, Şener vd. Eğitimde Bilimsel Araştırma Yöntemleri. Ankara: Pegem Akademi, 2018.

Calp, Mehrali. “Türk Dili ve Edebiyatı Bölümü Öğrencilerinin Osmanlı Türkçesindeki Okuma Hataları Üzerine Bir Çalı̧̧ma.” Uluslararası Türkçe Edebiyat Kültür Eğitim Dergisi (TEKE), 6, 3 (2017): 1679-1705.

Calp, Mehrali. "Osmanlı Türkçesi Dersini Alan Öğrencilerin Yaptıkları Okuma, Yazma ve Gramer Hatalarının Sebepleri ve Sağaltmaları Üzerine Bir Araştırma.” Kastamonu Eğitim Dergisi, 27, 4 (2019): 1757-1779.

Çalışkan, Nihal. "Lise Düzeyindeki Osmanlı Türkçesi Dersi Öğretim Programının Uygulanışına İlişskin Öğrenci Görüşlerine Dayalı Bir Değerlendirme.” Bartın Üniversitesi Eğitim Fakültesi Dergisi, 2, 2 (2013): 329-343. 
Demir, Nurettin ve Yılmaz, Emine (2013). “Türkçenin Tarihi Dönemleri.” Türk Dili Yazılı Ve Sözlü Anlatım, (2013): 43-50. (Ed. Nurettin Demir, Emine Y1lmaz) içinde. Ankara: Nobel.

Demir, Nurettin ve Y1lmaz, Emine. Türk Dili El Kitabı. Ankara: Grafiker, 2016.

Develi, Hayati. Osmanlı'nın Dili. İstanbul: Kesit, 2013.

Eker, Süer. Çăgdaş Türk Dili. Ankara: Grafiker, 2013.

Ergin, Muharrem. Türk Dil Bilgisi. İstanbul: Bayrak, 1997.

Ergüzel, M.Mehdi. "Millî Eğitimde Osmanlı Türkçesinin Seçmeli Ders Olarak Öğretilmesi Üzerine.” Turkish Studies, 10, 8 (2015): 35-42.

Johanson, Lars. Türkisch. Variationstypologie / Variation Typology (2004):919-944 içinde. (Ed. Thorsten Roelcke), Berlin-New York: Walter de Gruyter

Kahya, Hayrullah. “Osmanlı Türkçesi (Osmanlıca) Ne Değildir?” VI. Yıldız Uluslararası Sosyal Bilimler Kongresi Tam Metin Bildiri Kitabl, 12-13 Aralık, 2019, İstanbul, 814-819.

Kahya, Hayrullah. "Türkçe Öğretmen Adaylarının Osmanlı Türkçesi Dersi Hakkındaki Düşünceleri.” VI. Yıldız Uluslararası Sosyal Bilimler Kongresi Özet Bildiri Kitabı, 12-13 Aralık, 2019, İstanbul, 328.

Kaplan, Mehmet. Kültür ve Dil. İstanbul: Dergah, 2019.

Karaağaç, Günay. Türkçe Verintiler Sözlüğü. Ankara: TDK, 2008.

Kaya, Ramazan. "Tarih Öğretmen Adaylarının Lisans Eğitiminde Osmanlıca Öğretiminin İşlevselliği İle İlgili Görüşleri.” Atatürk Üniversitesi Sosyal Bilimler Enstitüsü Dergisi, 17, 2 (2013), 187-206.

Korkmaz, Zeynep. Türk Dili Üzerine Araştırmalar. Ankara: TDK, 1995.

Türkçe Sözlük (Ankara: Türk Dil Kurumu Yayınları). Erişim 30.10.2019. https://sozluk.gov.tr adresinden erişildi. Levend, A.Sırrı. Türk Dilinde Gelişme ve Sadeleşme Evreleri. Ankara: TDK, 1972.

Miles, Matthew B., ve Huberman, A. Michael. Qualitative data analysis: An expanded Sourcebook. (2nd ed). Thousand Oaks, CA: Sage, 1994.

Özkan, Bülent ve Şahbaz, N. Kemal. “Türkçe Öğretmeni Adaylarının Alan Derslerinin İşlevselliğine Yönelik Görüşleri." Sakarya University Journal of Education, 1, 1 (2011), 32-43.

Özkan, Mustafa (2007). Osmanlı Türkçesi. TDV İslam Ansiklopedisi, cilt 33, İstanbul: TDV, (2007):483-485.

Özkan, Mustafa. Tarih İçinde Türk Dili. İstanbul: Filiz, 1997.

Özmen, Necmettin ve Yıldırım, Bilal. “Üniversite Öğrencilerinin Osmanlı Türkçesine İlişkin Tutumları.” Dil ve Edebiyat Araştırmaları, 16 (2017): 49-66.

Sevim, Oğuzhan ve Bayındır, Hatice. "Lise Ve Üniversite Öğrencilerinin Osmanlı Türkçesi Dersine Yönelik Görüşlerinin İncelenmesi.” Ekev Akademi Dergisi, 20, 67 (2016): 291-302.

Timurtaş, F.Kadri. Osmanlı Türkçesi III. İstanbul: Alfa, 2003.

Timurtaş, F.Kadri. Diller ve Türkçemiz. İstanbul: Alfa, 1996.

Ulucan, Mehmet. “Osmanlı Türkçesinin Öğretimi.” Milli Eğitim, 212 (2016): 93-113.

Yıldırım, Ali ve Şimşek, Hasan. Sosyal Bilimlerde Araştırma Yöntemleri (8. baskı). Ankara: Seçkin, 2011.

Yılmaz, Malik ve Şenay, B. Aydemir. “Türkiye'deki Bilgi ve Belge Yönetimi Bölümlerinin Lisans Ders Programlarında Yer Alan Osmanlı Türkçesi Derslerinin Değerlendirilmesi ve İstihdamdaki Önemi.” Atatürk Üniversitesi Sosyal Bilimler Enstitüsü Dergisi, 18, 3 (2014): 1-10. 